\title{
Republic of Congo: Enhanced Heavily Indebted Poor Countries (HIPC) Initiative-Preliminary Document
}

This paper was prepared by staff of the International Monetary Fund and the World Bank in connection with the Executive Board's consideration of the Republic of Congo's preliminary assessment of eligibility for assistance under the enhanced Initiative for Heavily Indebted Poor Countries. It is based on the information available at the time it was completed on July 19, 2005. The views expressed in this document are those of the staff team and do not necessarily reflect the views of the government of the Republic of Congo or the Executive Board of the IMF.

The policy of publication of staff reports and other documents by the IMF allows for the deletion of market-sensitive information.

To assist the IMF in evaluating the publication policy, reader comments are invited and may be sent by e-mail to publicationpolicy@imf.org.

Copies of this report are available to the public from

International Monetary Fund • Publication Services

700 19th Street, N.W. • Washington, D.C. 20431

Telephone: (202) 6237430 • Telefax: (202) 6237201

E-mail: publications@imf.org • Internet: http://www.imf.org

Price: $\$ 15.00$ a copy

\section{International Monetary Fund Washington, D.C.}





\section{INTERNATIONAL DEVELOPMENT ASSOCIATION INTERNATIONAL MONETARY FUND}

\section{REPUBLIC OF CONGO}

\section{Enhanced Heavily Indebted Poor Countries (HIPC) Initiative—Preliminary Document}

Prepared by the Staffs of the International Monetary Fund and the World Bank

Approved by Anthony Boote and Thomas Krueger (IMF) and

Gobind T. Nankani and Daniel Leipziger (IDA)

July 19, 2005

Contents

Page

I. Introduction 4

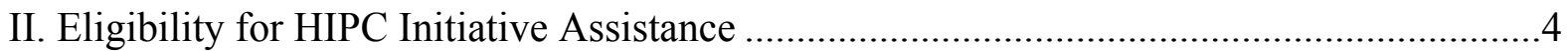

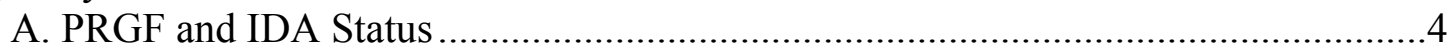

B. Poverty and Social Development .........................................................................

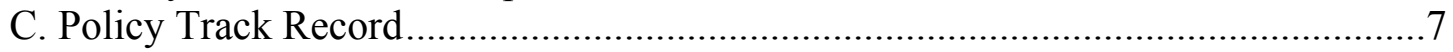

III. Medium-to-Long-Term Macroeconomic Framework ……………....................................

IV. Debt Sustainability Analysis and Possible HIPC Assistance ………................................12

A. Debt Reconciliation Status..........................................................................12

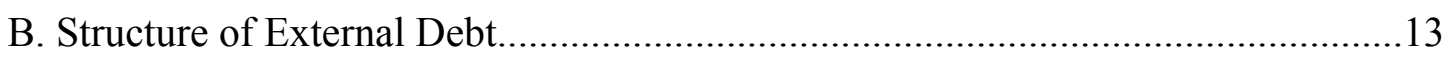

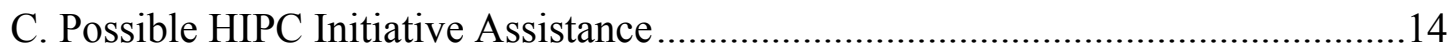

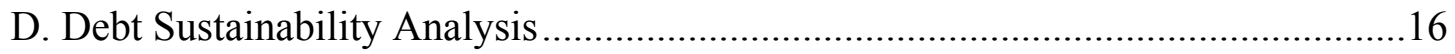

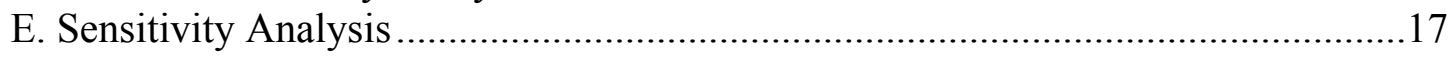

V. The Decision and Floating Completion Points ………......................................................17

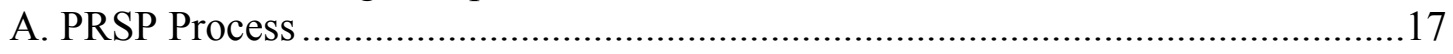

B. Possible Decision Point Timing ..............................................................................18

C. Possible Triggers for the Decision and Floating Completion Points .......................18

D. Monitoring the Use of HIPC Initiative Resources ...................................................20

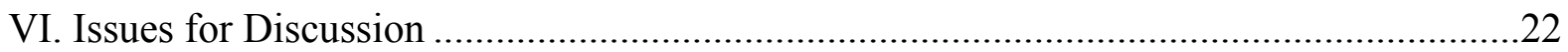


Boxes

1. Selected Poverty and Living Standard Indicators .................................................5

2. Selected Economic and Social Performance Indicators, 1980-2004 ............................6

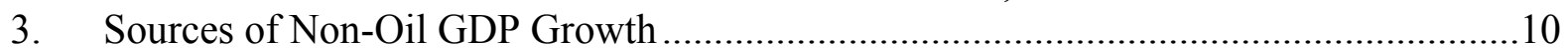

4. External Arrears Clearance ................................................................................ 15

5. Possible Triggers for the Floating Completion Point ...............................................19

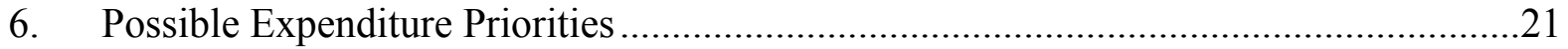

Figures

1. Net Present Value of Outstanding Debt at end-2003 by Creditor Group ...................23

2. External Debt Profile External Sustainability Indicators, 2004-23 .........................24

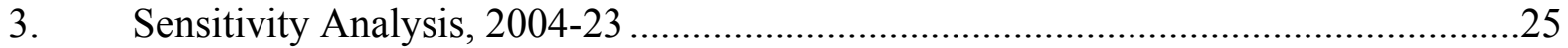

\section{Tables}

1. Selected Economic and Financial Indicators, 2001-07 .........................................26

2. Selected Indicators of Long-Term Macroeconomic Projections, 2005-23 ................27

3. Nominal Stock and Net Present Value of Debt at end-2003 by Creditor Group.........28

4. Net Present Value of External Debt, 2003-23 ....................................................29

5. HIPC Initiative Assistance Under a Proportional Burden-Sharing Approach..............30

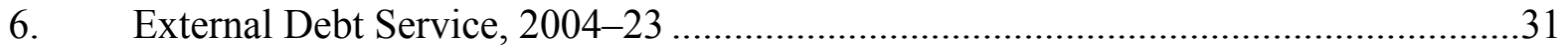

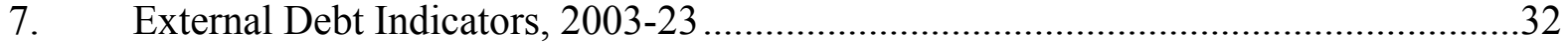

8. External Debt Indicators and Sensitivity Analysis, 2004-23 ...................................33

9. Possible Delivery of World Bank Group's Assistance Under the Enhanced

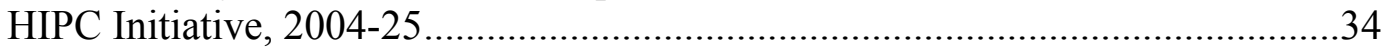

10. Possible Delivery of IMF Assistance Under the Enhanced

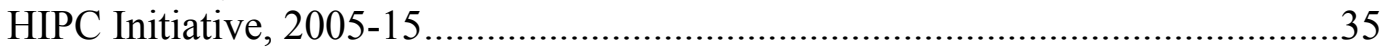

11. HIPC Initiative: Status of Country Cases Considered Under

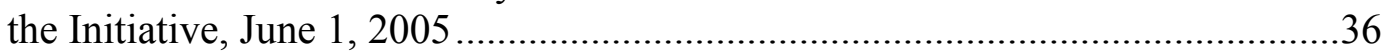

Appendices

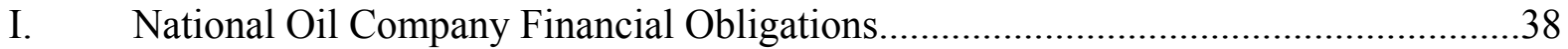

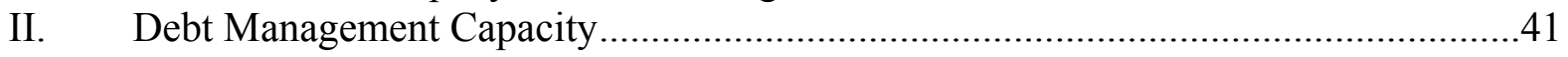




\section{Abbreviations and Acronyms}

AfDB
BDEAC
DSA
EMRRP
GDP
HIPC Initiative
EITI
IBRD
IDA
IMF
I-PRSP
MDBs
MDGs
MONUC
NPV
PRGF
PRSP
ROC
SDR
SMP
TSS
UNDP
UNICEF

African Development Bank

Banque de Développement des Etats de l'Afrique Centrale

Debt Sustainability Analysis

Emergency Rehabilitation and Reconstruction Program

Gross Domestic Product

Heavily Indebted Poor Countries Initiative

Extractive Industries Transparency Initiative

International Bank for Reconstruction and Development

International Development Association

International Monetary Fund

Interim Poverty Reduction Strategy Paper

Multilateral Development Banks

Millennium Development Goals

United Nations Organization Mission

Net Present Value

Poverty Reduction and Growth Facility

Poverty Reduction Strategy Paper

Republic of Congo

Special Drawing Rights

Staff-Monitored Program

Transitional Support Strategy

United Nations Development Programme

United Nations Children's Fund 


\section{INTRODUCTION}

1. This paper presents a preliminary assessment of the eligibility of the Republic of Congo (hereafter "Congo") for assistance under the Enhanced Heavily Indebted Poor Countries (HIPC) Initiative. The findings are based on several joint IDA-IMF missions to Brazzaville, most recently in May 2005. Together with the authorities, the missions conducted a preliminary debt sustainability analysis (DSA). The results show that Congo's external debt burden would remain above the HIPC threshold even after application of traditional debt-relief mechanisms, with a ratio of net present value of debt to government fiscal revenues well above the threshold of 250 percent on the basis of end-2003 data. ${ }^{1}$ Debt relief under the enhanced HIPC Initiative would help accelerate progress toward meeting the Millennium Development Goals (MDGs), although capacity constraints would need to be tackled to enable absorption of related resources.

2. Section II provides background information on eligibility under the enhanced HIPC Initiative, the incidence of poverty, and the policy track record to date. Section III discusses the medium-to-long-term macroeconomic projections. Section IV presents the preliminary DSA, incorporating possible assistance under the enhanced HIPC Initiative. Section V outlines the proposed timeline for preparation of the decision point document and the proposed key reforms to be considered for the completion point triggers, and gives a preliminary indication of how debt-service savings after the decision point will be used and tracked. Finally, Section VI includes issues for discussion by Executive Directors.

\section{ELIGIBILITY FOR HIPC INITIATIVE AsSISTANCE}

\section{A. PRGF and IDA Status}

3. Congo is an IDA-only country, with a GNI per capita of US\$770 in 2004 (using World Bank's Atlas methodology)—Box 1. On December 6, 2004 the Executive Board of the IMF approved a three-year arrangement under the PRGF for Congo in an amount equivalent to SDR 54.99 million (65 percent of quota). Congo will continue to need concessional assistance from the international community and is likely to remain an IDAonly country and eligible for PRGF resources for the foreseeable future.

\section{B. Poverty and Social Development}

4. Once classified as a lower-middle-income economy, Congo experienced a continuous decline in per capita income from the mid-1980s to the late-1990s. Per capita real GDP in 2003 was about 70 percent of its level in 1984, resulting in increased poverty, especially in the 1990s. This adverse trend coincided with the overvaluation of the CFA franc in the second half of the 1980s, three conflicts in the 1990s, and continuing institutional weaknesses.

\footnotetext{
${ }^{1}$ As a very open economy, Congo would qualify for debt relief under the fiscal window.
} 


\begin{tabular}{|c|c|c|}
\hline \multicolumn{3}{|c|}{$\begin{array}{c}\text { Box 1. Selected Poverty and Living Standard Indicators } \\
\text { (In percent, unless otherwise specified) }\end{array}$} \\
\hline Indicator & Republic of Congo & $\begin{array}{r}\text { Sub-Saharan } \\
\text { Africa }\end{array}$ \\
\hline Population (in millions, 2004) & 3.8 & 688 \\
\hline Population growth (in percent) & 3.0 & 2.4 \\
\hline GNI per capita (U.S. dollars, 2004) & 770 & 450 \\
\hline Life expectancy (years) & 52 & 46 \\
\hline Infant mortality rate (per thousand) & 81 & 105 \\
\hline Child under 5 mortality rate (per thousand, 2003) & 108 & $\ldots$ \\
\hline Maternal mortality rate (per 100,000 live births) & 510 & $\ldots$ \\
\hline Adults and children living with HIV/AIDS (excludes orphans, 2001) & 110,000 & $\ldots$ \\
\hline Of which:, children aged $0-14$ & 15,000 & $\ldots$ \\
\hline adults aged $15-49$ & 99,000 & \\
\hline women aged $15-49$ & 59,000 & $\ldots$ \\
\hline Orphans, aged 0-14, living with HIV/AIDS (2001) & 78,000 & $\ldots$ \\
\hline $\begin{array}{l}\text { Illiteracy rate (percent of population age } 15+\text {, latest single year } \\
\text { available 1996-2002) }\end{array}$ & 17 & 37 \\
\hline $\begin{array}{l}\text { Gross primary enrollment rate (percent of school age population, } \\
\text { latest single year available 1996-2002) }\end{array}$ & 97 & 86 \\
\hline Of which: Male & 101 & 92 \\
\hline Female & 93 & 80 \\
\hline \multicolumn{3}{|l|}{ Impact of conflicts in the $1990 \mathrm{~s}$} \\
\hline Child soldiers & 5,000 & \\
\hline Displaced persons & $1,000,000$ & \\
\hline
\end{tabular}

Sources: World Bank, Economic and Social Indicators.

5. Successive and intense rounds of civil wars (1993, 1997, and 1998-99) resulted in the extensive loss of human lives and negative socio-economic consequences (Box 2). It is estimated that 70 percent of the population lives below the poverty line (defined as US\$1 per day) compared to about 30 percent in 1993. The 2004 United Nations human development index ranked Congo 144th out of a total of 177 countries. The pervasiveness of poverty is further reflected in labor force statistics. Unemployment affects more than 50 percent of the active population, with youth being particularly affected.

6. Human resource development programs are being implemented to rehabilitate education and health infrastructure destroyed during the war and to improve the provision of services. In the education sector, the government has prepared an "Education for All Action Plan" which aims to diversify and improve education services through the decentralization of management and delivery of services, the strengthening of partnerships with civil society, and improving the quality of education services and of the efficiency and transparency in the management of the system. There are two major problems in the health sector: poor 
infrastructure, as over half of all health facilities in the country were destroyed or damaged during the civil conflicts; and lack of qualified personnel. The HIV/AIDS pandemic is further placing a strain on Congo's health system. The government adopted a three-year plan to prevent the transmission of STDs and HIV/AIDS, care for the sick, conduct epidemiological surveillance, decentralize health activities, train health personnel, and carry out research. The Ministry of Education has joined the campaign against HIV/AIDS by educating students.

\begin{tabular}{|c|c|c|c|c|c|}
\hline \multicolumn{6}{|c|}{ Box 2. Congo: Selected Economic and Social Performance Indicators, 1980-2004 } \\
\hline & $1980-84$ & $1985-89$ & $1990-94$ & $1995-99$ & $2000-04$ \\
\hline National accounts & \multicolumn{5}{|c|}{ (In percent, unless otherwise indicated) } \\
\hline Per capita GDP (in 1995 US dollars) & 982 & 979 & 883 & 796 & 795 \\
\hline Real GDP growth & 14.3 & -0.7 & -0.1 & 1.7 & 4.2 \\
\hline Oil & 12.5 & 9.3 & 3.8 & 9.1 & -3.3 \\
\hline Nonoil & 14.9 & -3.3 & -1.7 & -2.8 & 9.6 \\
\hline \multirow[t]{2}{*}{ Consumer price inflation } & 3.7 & -2.8 & 9.0 & 7.4 & 1.9 \\
\hline & \multicolumn{5}{|c|}{ (In percent of GDP, unless otherwise indicated) } \\
\hline \multicolumn{6}{|l|}{ Fiscal accounts } \\
\hline Total domestic revenue (excl. grants) & 34.1 & 25.8 & 24.3 & 25.7 & 29.1 \\
\hline Primary expenditure and net lending 1/ & 24.3 & 22.9 & 26.4 & 21.6 & 22.4 \\
\hline Basic primary budget balance & 9.8 & 2.9 & -2.2 & 4.2 & 6.7 \\
\hline \multicolumn{6}{|l|}{ External sector } \\
\hline Trade balance & 23.3 & 25.6 & 24.3 & 40.1 & 53.3 \\
\hline External debt & 89.6 & 176.6 & 217.5 & 236.9 & 180.8 \\
\hline Real effective exchange rate (index, $1990=100$ ) & 96.7 & 98.8 & 92.7 & 79.3 & 80.8 \\
\hline Terms of trade (index, 1990=100) & 179.6 & 125.8 & 84.1 & 78.0 & 127.4 \\
\hline Oil price (U.S. dollars per barrel) & 33.3 & 18.7 & 19.2 & 17.4 & 28.9 \\
\hline Social indicators & \multicolumn{5}{|c|}{ (In units indicated) } \\
\hline Adult illiteracy ratio (in percent of people ages 15 and above) & 46 & 38 & 30 & 23 & 19 \\
\hline Secondary school enrollment ratio 2 / & 74 & 75 & 54 & 53 & 42 \\
\hline Immunization ratio $3 /$ & 50 & 70 & 67 & 33 & 31 \\
\hline Life expectancy at birth ( in years) & 50 & 51 & 51 & 51 & 51 \\
\hline \multicolumn{6}{|c|}{$\begin{array}{l}\text { Sources: Congolese authorities, and staff estimates and calculations. } \\
\text { 1/ Noninterest current expenditure plus domestically-financed investment. } \\
\text { 2/ In percent of the children of secondary school age. } \\
\text { 3/ In percent of children under } 12 \text { months for immunization against diphtheria, tetanus, and polio. }\end{array}$} \\
\hline
\end{tabular}

7. Congo is highly urbanized, with roughly 70 percent of the population residing in urban areas. Urban living conditions are characterized by the imbalance between inner-city neighborhoods, which are sparsely populated and have access to functioning infrastructure, and the peripheral neighborhoods, which are densely populated and lack basic socioeconomic amenities. The government, in the context of the I-PRSP, has outlined an urban strategy which will update urban development policies, rehabilitate the urban road network and link roads in the dense and inaccessible neighborhoods, adopt an urban environmental management strategy, support small-scale urban enterprises, and improve urban governance and the collection of local taxes. 


\section{Policy Track Record}

8. Emerging from a conflict situation, and starting from a very low base, Congo has made significant progress in implementing financial and structural reforms, but large challenges remain. These include the need to address widespread and primarily urban poverty, continue to demobilize armed combatants, and enhance transparency in the management of Congo's natural resources.

9. Peace and security have improved since a new government was appointed following a constitutional referendum and presidential, legislative, local, and senatorial elections, all held during January-June 2002. ${ }^{2}$ Since then, the government has signed a peace accord with a hold-out rebel group, and over the past year has launched a program to demobilize former combatants and reestablish democratic institutions. Nonetheless, the security situation remains fragile, as indicated by the recent attacks by a rebel group which forced suspension of services on the vital Brazzaville-Pointe Noire rail line, and the rebel attack on a UNDP convoy in the Pool region that occurred in April 2005.

10. The overall improving political and security conditions allowed the authorities to make good progress toward restoring macroeconomic and financial stability. Since end-2002, the government has focused on the country's economic and social recovery within the framework of its "Nouvelle Espérance" (New Hope) program. This effort was supported by the Fund's Emergency Post Conflict Assistance (in an amount equivalent to SDR 10.6 million) in 2000 and the close monitoring of the authorities' efforts to strengthen the framework for policy implementation through four staff-monitored programs (SMP) during 2001-04. The IMF Executive Board approved a new three-year PRGF arrangement last December to support the government's economic program through 2007. The government's effort has also been bolstered by IDA through balance of payments support (a Post Conflict Economic Recovery Credit of US\$37.6 million in July 2001), and an Economic Recovery Credit of US\$30 million in December 2004. ${ }^{3}$ The African Development Bank (AfDB), European Union, and bilateral donors have also provided important assistance. In addition, an agreement was reached on December 16, 2004 between Paris Club creditors and Congo for a debt stock reduction and arrears rescheduling.

11. The onset of peace in $1999 / 2000$ boosted economic activity and contributed to macroeconomic stability (Box 2 above). Stronger economic performance in the post-conflict

\footnotetext{
${ }^{2}$ The cabinet was reshuffled in early January 2005.

${ }^{3}$ IDA also has several ongoing investment projects, including (i) a Transparency and Governance Capacity Building Project for US\$7 million; (ii) an Emergency Infrastructure Rehabilitation and Reconstruction Project for US\$40 million; (iii) an Emergency Recovery Community Support Project for US\$41 million; (iv) an HIV/AIDS and health project for US\$19 million; and (v) a Support to Basic Education Project for US\$20 million.
} 
period was helped not only by enhanced macroeconomic management, but also by the rise in oil prices from about US\$171/2 per barrel on average during 1995-99 to about US\$29 during 2000-04. Non-oil real GDP increased by about $9 \frac{1}{2}$ percent per annum on average during 2000-04, propelled by improvements in agriculture, commerce and transportation. The basic primary fiscal balance has improved since the late 1990s. Consumer price inflation decelerated significantly, helped by the trend toward fiscal consolidation, a more reliable supply line from Pointe-Noire to Brazzaville, and a strengthening of the euro (to which the CFA franc is tied) vis-à-vis the U.S. dollar.

12. Following repeated setbacks in the implementation of economic reforms under the 2001-03 SMPs, a noticeable break with the past cycle of poor governance and weak economic management has been observed since late 2003:

- The recent significant improvement in the fiscal position is attributable to tighter control of expenditure, high oil revenues, and mobilization of nonoil revenues. Noteworthy public finance reforms have included: (i) the centralization of a large portion of fiscal revenues and expenditures in the budget; (ii) the appointment of new senior officials in the General Directorates of the Budget, Customs, and Taxes, as well as in the Office of the Inspector-General of Finance, to revamp the revenue administration agencies and strengthen control; and (iii) improved tracking of oil revenues and budgetary expenditures.

- The government placed strong emphasis on governance, especially in enhancing oil sector transparency, and more broadly natural resource sector transparency. Unprecedented in Africa has been the authorities' emphasis on internet publication, including of quarterly reports on oil revenue certification, as well as internet publication of the full 2003 audit report of the national oil company (SNPC), the terms and conditions of the financial transactions carried out by the SNPC for the government, and all active production-sharing agreements. The authorities have also announced their commitment to adhere to the Extractive Industry Transparency Initiative (EITI).

- Significant steps have been taken to improve relations with creditors since the beginning of 2003 (see Section IV.B and Box 4 below). The government has contracted no new loans with maturity exceeding one year using oil as collateral since October 2002.

\section{MEDIUM-TO-LONG-TERM MACROECONOMIC FRAMEWORK}

13. The macroeconomic projections used in this analysis were prepared jointly with the authorities and extend to 2023 (Tables 1 and 2). The forecasts are based on the assumptions of sound macroeconomic policies, increased investment in infrastructure and human capital, structural reforms that promote a business-friendly environment and output diversification, policies that significantly enhance transparency and governance and promote sound institutions and the rule of law. These policies and reforms are critical to boosting growth and helping Congo to make significant progress toward meeting the MDGs. The baseline 
scenario assumes that Congo benefits from traditional debt relief mechanisms, with a significant downward impact on debt service.

14. Real GDP growth is projected at about 4.7 percent per year during 2005-23, accompanied by a significant rise in investment (Table 2; Box 3). In view of depleting oil production, the nonoil sector's importance is projected to rise significantly over the long run from about 50 percent in 2004 to some 80 percent by 2023. Oil production is expected to increase until 2010 as new oil fields come on stream, and then to decline over the following two years as the positive effect is offset by the depletion of older oil fields. On average, oilsector real GDP is projected to grow by about 1 percent per annum over 2005-23. Nonoil real GDP growth, by contrast, is projected to accelerate steadily over the period, largely on account of higher investment, reflecting the positive impact of structural reforms designed in particular to promote greater private sector activity. The projected economic growth is below that needed to halve the proportion of the population living below the poverty line (i.e., about 8 percent per annum in the nonoil sector), but it is considered realistic and therefore likely to be achievable and sustainable.

15. Fiscal revenues (including oil and nonoil) are projected at about $271 / 2$ percent of GDP per year on average during 2005-23, compared to 29 percent on average over 2000-04. Nonoil revenues are projected to rise steadily to about 16 $1 / 2$ percent of GDP by 2023 (from around 9 percent in 2004). A number of recent measures were taken to widen the tax base and extend the reach of the central administration. ${ }^{4}$ Medium-to-long-term measures to enhance nonoil revenues include: conduct of regular tax audits; establishment of computerized links between the various customs and tax administration offices; use of the single taxpayer identification number; and elimination of discretionary tax exemptions. It is expected that compliance by taxpayers would rise significantly on the basis of improved government services. Oil revenues are projected to be lower by almost 6 percentage points of GDP per year on average during 2005-23 (relative to 2000-04), reflecting the decline in the oil sector's importance.

16. The composition of public expenditures is expected to shift in favor of capital outlays over the long term. In line with the authorities' I-PRSP, the projections assume that the share of pro-poor spending in overall outlays will increase in order to allow Congo to make progress in achieving the MDGs. The authorities are determined to better track public spending. Specifically, they plan to (i) strengthen the framework for tracking expenditures from the commitment to the payment stage, and (ii) complete the introduction of a functional and economic classification in the budget nomenclature, already underway with technical assistance from the IMF and the World Bank. The authorities intend to improve their

\footnotetext{
${ }^{4}$ These include the systematic transfer of revenues to the Treasury, widening territorial coverage of tax and customs administrations, improvement in computer linkages at the customs office in Pointe Noire, reinforcement of the customs and tax administrations, and strengthening management of the value-added tax.
} 
tracking of poverty-related expenditures, with assistance from the World Bank, and plan to review the public procurement system.

\section{Box 3. Sources of Non-Oil GDP Growth}

A growth-accounting framework with the following production function is used to analyze Congo's non-oil economic growth experience and prospects: $Y=A L^{0.6} K^{0.4}$, where $Y$ is non-oil real GDP; $A$, typically known as the Solow residual, represents total factor productivity (TFP); $L$ is the labor force, and $K$ is physical capital in the non-oil sector. This exercise suffers from a number of weaknesses. In particular, the capital stock series has been constructed using simplifying assumptions (e.g., related to the depreciation rate and beginning-of-period stock) and may contain significant errors, especially during the conflict period. The results are summarized below:

\begin{tabular}{|c|c|c|c|c|c|c|}
\hline \multicolumn{7}{|c|}{$\begin{array}{l}\text { Congo: Sources of Non-Oil GDP Growth, 1970-2023 } \\
\text { (In percentage change; unless otherwise indicated) }\end{array}$} \\
\hline & $1970-79$ & $1980-89$ & $1990-99$ & $2000-04$ & $1970-89$ & $\frac{2005-23}{\text { Proj. }}$ \\
\hline Non-oil real GDP growth: & 3.6 & 5.8 & -2.3 & 9.6 & 4.7 & 6.0 \\
\hline Factor accumulation 1/ & 3.6 & 3.5 & 1.9 & 5.1 & 3.6 & 4.8 \\
\hline Solow residual & 0.0 & 2.3 & -4.2 & 4.5 & 1.1 & 1.2 \\
\hline \multicolumn{7}{|l|}{ Memorandum items: } \\
\hline Labor growth & 2.5 & 2.8 & 2.9 & 2.9 & 2.7 & 2.7 \\
\hline Capital stock growth & 5.2 & 4.5 & -2.6 & 8.4 & 4.9 & 8.0 \\
\hline
\end{tabular}

Sources: Congolese authorities; and Fund staff calculations.

1/ Accumulation of capital and labor, using 0.4 and 0.6 as factor shares, respectively.

- Factor accumulation explained the bulk of non-oil output growth during 1970-2004, with TFP playing a limited role.

- The devastating impact of the civil wars of the 1990s is evident in the sharp deceleration of factor accumulation and the negative Solow residual.

- The pickup in non-oil output since the war ended - accompanied by a significant catch-up in productivity - is impressive.

- The growth forecast for 2005-23 is predicated on greater factor accumulation and a slightly larger Solow residual (or total factor productivity growth). Investment is expected to be larger by about 6 percentage points of GDP per year on average between 2000-04 and 2005-23 on account of an improved business environment accompanied by complementary government investment in physical and human capital. Faster productivity growth is expected to come mainly from (i) the secondary impact of increased investment in the oil sector, and (ii) a pickup in overall productivity stemming from structural reforms and infrastructure investments. 
17. The overall budget balance is projected to remain positive throughout the forecast period, but to decline significantly from 2012 onward reflecting a projected decline in oil revenues. The authorities are implementing a conservative fiscal rule regarding oil revenue projections; under the rule, oil revenues (and, consequently, expenditures) should be projected on the basis of conservative oil projections (IMF, WEO projected price minus US\$4 per barrel).

18. Export volume is expected to grow by $3 \frac{1}{2}$ percent per year on average during 2005-23. The share of oil exports is projected to decline from 65 percent of GDP in 2004 to less than 30 percent by 2023 . The Congo has an immediate balance of payments need. The rescheduling of arrears to Paris Club creditors is projected to raise debt service to about 8 percent of GDP a year on average over the period 2005-07. In 2005, however, financing is assured thanks to resources already committed by bilateral and multilateral donors, and financing assurances provided by Paris Club creditors. Nonetheless, large external arrears to commercial creditors, amounting to some US\$2.5 billion, and debt service due to Paris Club creditors (past the 6 years grace period) give rise to large financing needs. Further debt relief will be key to meeting the financing requirements.

19. Congo is burdened with a large internal debt stock, which stood at about CFAF 560 billion at end-2003 (27 percent of GDP), with social debt (e.g., salary and pension arrears) amounting to about CFAF 240 billion. The authorities are committed to preparing a comprehensive plan to settle domestic arrears, and to publish the related policy framework on the internet. To meet pressing social needs, the government signed a "social truce" with the labor unions under which the gradual clearance of arrears on wages and pensions began in 2004. Additionally, the government will settle its domestic arrears on other categories of debt on the basis of the domestic arrears settlement plan mentioned above.

20. Private sector development is key to pro-poor growth. A one-stop tax window has been established to streamline the tax burden on enterprises. Actions underway to promote the sector include reforming the legal and judicial framework for business, with assistance from the World Bank, including better guarantees on property rights and the independence of the judiciary. Progress with privatization in the areas of refined petroleum products distribution, as well as banking and telecommunications, are expected to be consolidated. With World Bank assistance, the water and electricity utilities will be rehabilitated and their management upgraded in order to improve service delivery and the prospects of privatization. Efforts should continue to complete the concession of the vital Pointe NoireBrazzaville railways link. Finally, efforts to improve government/taxpayer relations by promoting unrestricted public access to comprehensive tax and customs laws and regulations are under way, including through their dissemination in the Journal Officiel.

21. Congo faces significant challenges in agriculture and rural development. Key among these challenges are production and marketing constraints. Production constraints arise primarily from use of primitive technologies and limited support from research and agricultural extension services. Marketing constraints result from high market transaction costs due mainly to inefficient rural transport infrastructure. In 2003, the government of 
Congo developed a policy framework for developing its agricultural sector, which was subsequently adopted by the Council of Ministers in late 2003. The major objectives of the national agricultural policy focused on increasing food security, reducing food imports, revitalizing agricultural exports, creating jobs in rural areas, reducing rural-urban migration, managing natural resources in a sustainable manner, and diversifying sources of growth in the economy. The authorities have actively sought the participation of the donor community and grassroots organizations.

\section{Debt Sustainability Analysis and Possible HiPC Assistance}

\section{A. Debt Reconciliation Status}

22. The DSA presented below was prepared jointly by the authorities and the staffs of IDA and the IMF, based on loan-by-loan data provided by the authorities and creditors for debt outstanding and disbursed as of end-December 2003. Debt reconciliation began in August 2003 during a joint IDA-IMF mission and continued in May 2004 during another joint mission. The reconciliation process has been completed for multilateral debt and much progress has been made in reconciling the debt of bilateral and commercial creditors. Given the large shares of the official bilateral and commercial debt in the total debt stock (59 percent and 33 percent, respectively), more work in this area is required before reaching Decision Point under the enhanced HIPC Initiative. However, about 70 percent of external debt has been reconciled with creditors as of end-2003. ${ }^{6}$ The debt estimates and NPV calculations presented below are therefore preliminary, pending further information from bilateral and commercial creditors.

\footnotetext{
5 The DSA underlying the Decision Point document will be prepared on the basis of end2004 debt data.

${ }^{6}$ Reconciliation discussions on bilateral debt took place in the context of the 2004 Paris Club agreement, and commercial debt was partially reconciled with the London Club group of creditors in 2004.
} 


\section{B. Structure of External Debt}

23. Congo's public and publicly guaranteed external debt is estimated to be US $\$ 8.5$ billion in nominal terms, or US $\$ 8.4$ billion in net present value (NPV) terms as of end-December 2003 (Table 3). This level of debt corresponds to an NPV of debt of 806 percent of fiscal revenue, 338 percent of exports, and 235 percent of GDP as of end-2003.

24. There are a number of features of Congolese debt that make it relatively unique among HIPCs. Some of the same characteristics could also pose challenges in obtaining financing assurances to meet the $70(80)$ percent

\begin{tabular}{|lrr|}
\hline \multicolumn{3}{|c|}{$\begin{array}{c}\text { Congo: Net Present Value of External Debt, end-2003 } \\
\text { (In units indicated) }\end{array}$} \\
\hline & NPV of Debt \\
\cline { 2 - 3 } & U.S. dollars & of total \\
\hline Total 1/ & 8,385 & 100 \\
Multilateral & 558 & 7 \\
Official bilateral & 4,982 & 59 \\
Paris Club & 4,675 & 56 \\
Other & 307 & 4 \\
Commercial & 2,845 & 34 \\
Memorandum items: & 481 & 6 \\
Oil-collateralized debt & 4,920 & $\ldots$ \\
NPV of debt after traditional relief 2/ & 473 & $\ldots$ \\
In percent of government revenue & 197 & $\ldots$ \\
In percent of exports & & \\
\hline Sources: Congolese authorities; and Fund and Bank staff estimates & \\
and calculations. & & \\
1/ Excluding potential debt of the SNPC. & & \\
2/ Results of preliminary assessment under Naples terms. & & \\
\hline
\end{tabular}
threshold required for the IMF to provide its debt relief at the time of the Decision (Completion) Point under the enhanced HIPC Initiative (Table 3 and Figure 1).

- Together, debt to multilateral and official bilateral creditors accounts for about two thirds of the total debt stock. Multilateral debt represents only about 8 percent of the total stock and official bilateral debt accounts for 59 percent (the bulk of which is owed to Paris Club creditors).

- The remaining debt (33 percent) is owed to commercial creditors. Of this amount, about two thirds (or 21 percent of the total stock) is owed to London Club creditors. The rest is owed to creditors of oil-collateralized loans ( $5 \frac{1}{2}$ percent of total stock) and litigating creditors. A number of litigating creditors are seeking to seize Congo's assets, having obtained court judgments in their favor. For the Decision Point DSA, the stock of debt under litigation is likely to be higher ${ }^{7}$ because part of the debt is currently classified as London Club claims, but has actually been sold on the secondary market; and courtawarded claims could be much larger than the face value.

- Congo's debt stock has a very low grant element as evidenced by the fact that the stock of nominal debt is very close to its NPV, especially for the bilateral official and commercial debt.

\footnotetext{
${ }^{7}$ The exact amount will become clearer after a thorough reconciliation exercise.
} 
- Congo's state-owned oil company, the SNPC, has large financial obligations to international oil companies, of some US\$1 billion at end $2003 .{ }^{8}$ These obligations are the result of an industry practice whereby international oil companies enable developing country governments to participate in oil exploitation joint ventures by advancing to governments or national oil companies the costs of their equity participation. Given the complexity of this matter, the staff plans to deepen its analysis in order to provide a definitive view as to whether any part of these obligations can be considered debt for the DSA underlying the Decision Point under the enhanced HIPC Initiative. In this document, however, following the authorities' methodology, these obligations are not taken into account as part of the DSA exercise.

25. In December 2004, Congo received a Paris Club debt restructuring under Naples terms. After simulating this treatment for bilateral and commercial debt, and excluding the clearance of multilateral arrears, the stock of external debt outstanding in NPV terms is US\$5 billion as of end-2003 (Table 3). Congo made major efforts in 2003 and 2004 to put in place agreements to clear arrears to multilateral and bilateral creditors (Box 4). The decline in the NPV of debt resulting from the concessional rescheduling of arrears by multilaterals will be counted towards their contribution to debt reduction under the enhanced HIPC Initiative, in line with a methodology agreed with multilateral development banks (MDBs). ${ }^{9}$

\section{Possible HIPC Initiative Assistance}

26. Debt relief under the enhanced HIPC Initiative would reduce Congo's external debt by nearly one half (Table 4; Figure 2). After the full use of traditional debt-relief mechanisms, to bring the external debt-to-fiscal revenues ratio down from 473 percent at end-2003 to the target ratio of 250 percent implies a common reduction factor of 47.1 percent for all creditors, or relief in the amount of US\$2,319 million in NPV terms (Table 5). Of this amount, the contribution from multilateral creditors would amount to about US\$265 million in NPV terms, and relief from Paris Club bilateral creditors to about US\$1,265 million. Commercial creditors would be expected to provide a further US\$684 million of relief in NPV terms and other official bilateral creditors US\$105 million. Assuming the time profile and modalities laid out below, this translates into about US\$4,220 million of debt service relief over time. The following assumptions were made in projecting the time profile of possible enhanced HIPC Initiative assistance:

\footnotetext{
${ }^{8}$ Appendix I provides a summary of key related issues and questions that still remain.

${ }^{9}$ See "HIPC Debt Initiative: the Chairman's Summary of the Multilateral Development Banks' Meeting," March 6, 1998, IDA/Sec M98-90, Attachment.
} 


\section{Box 4. External Arrears Clearance}

The African Development Bank Group (AfDB) approved in July 2004 a framework for assisting post-conflict countries (PCC) to clear their AfDB arrears. Under this framework, the cost of clearing country arrears is shared by the country, donors, and the AfDB PCC facility. ${ }^{1}$ The proportion of the cost covered by each participant is determined on a caseby-case basis. For the Congo, the following framework was adopted: The country paid UA 34.3 million to clear a third of the total UA 100 million (US\$148.4) in arrears at end2003; donors (Norway, France and the European Commission) pledged UA 32.4 million; and the AfDB approved a UA 33.3 million grant from the PPC facility to complete the arrears clearance plan.

BADEA agreed on consolidating US\$25.6 million in arrears in October 2001. The arrears were to be repaid over 13 years on concessional terms. Congo failed to respect the agreement initially, but it resumed payments in 2003. Upon receipt of the overdue, BADEA agreed that the authorities could make the remaining repayments according to the profile set in the 2001 agreement.

The OPEC Fund implemented a Commodity Import Program (CIP) in 1999 amounting to $\$ 13$ million, but the original agreement was not respected. The authorities repaid US\$12.1 million in arrears at end-2003. A new loan that restructures the remaining amount will be repaid in 9 years, at concessional terms.

Arrears to the European Union totaling some US\$39.2 million will be cleared at the decision point with a grant from the EU through a reallocation of US\$38.2 million from the European Development Fund resources already pledged to Congo.

In 2003, Congo repaid SDR 2.9 million in arrears to IFAD and US\$1.5 million to the Banque de Développement des Etats de l'Afrique Centrale (BDEAC).

Paris Club creditors restructured the Congo's public external debt on December 16, 2004. A total of US $\$ 3,020$ million was treated. The agreement treats, under Naples terms, both accumulated arrears at end-September 2004 (including late interest) and current maturities falling due during October 1, 2004 -September 30, 2007. Pre-cut off date ODA debts were rescheduled over 40 years, with 16 years of grace. 67 percent of pre-cutoff-date commercial credits were cancelled; the remaining amount was rescheduled over 23 years, with 6 years of grace. Arrears on post-cutoff-date debt and a part of the interest due under the rescheduling were re-profiled over a period of 3 years (October 1, 2004 - September $30,2007)$.

The government hopes to settle arrears to commercial creditors participating in the framework of the London Club on terms comparable to those expected under the enhanced HIPC Initiative. Negotiations are under way with other official bilateral and commercial creditors.

\footnotetext{
${ }^{1}$ The PCC facility is a legal autonomous entity under the auspices of the African Development Fund (AfDF) for the sole purpose of providing grant resources to assist qualifying PCCs clear their AfDB Group arrears. The facility is financed from UA 100 million from the AfDB net income allocations, UA 100 million from ADF-10 resources, and UA 7 million from Nigeria Trust Fund income allocations.
} 
- Paris Club bilateral creditors. There would be a flow rescheduling on Cologne terms - i.e., a 90 percent NPV reduction — after reaching the Decision Point, with delivery of the remaining required assistance at the Completion Point through a stockof-debt operation.

- Comparable treatment would be provided by non-Paris Club official bilateral creditors and commercial creditors.

- IMF assistance would total US\$12.6 million in NPV terms. Immediately following the approval of the decision point by the Boards of IDA and the IMF, the IMF would provide interim assistance - provided that the necessary financing assurances are in place - in the form of debt-service reduction in 2005-07, covering current obligations, including interest on the PRGF arrangement approved in December 2004. Principal repayments on IMF PRGF loans will begin in August 2009. Most of the IMF's relief would be delivered following the Completion Point.

- IDA would provide total assistance amounting to US\$67.7 million in NPV terms. Immediately following the approval of the decision point by the Boards of IDA and the IMF, IDA would begin to provide debt service relief in the form of debt-service reduction on debt outstanding and disbursed at end-2003. Assuming that Congo reaches the completion point at end-2007, this debt service relief would continue until 2025.

- All other creditors are assumed to provide debt-service reduction starting at the decision point or the completion point, until their contributions meet the requirement under the enhanced HIPC Initiative.

\section{Debt Sustainability Analysis}

27. Congo is eligible for debt relief under the enhanced HIPC Initiative's fiscal window. In April 1997, the fiscal revenues/openness criteria were established to allow for the possibility that, for countries with a high export base, reaching the debt-to-export criteria targets may still leave the country with an unsustainable external debt burden relative to fiscal revenues. In order to qualify for this window, the country must have an export-to-GDP ratio of at least 30 percent, and a fiscal revenues-to-GDP ratio of at least 15 percent, using an average of the last three years of actual data. ${ }^{10}$ As of 2003, Congo's exports-to-GDP ratio was about 79 percent and its fiscal revenues-to-GDP ratio was about 29 percent.

28. Congo's debt-to-fiscal revenues ratio is projected to fall steadily from its end-2003 level (Table 4). On the basis of the assumptions above, and taking into account the phased-in

\footnotetext{
${ }^{10}$ Modifications to the Heavily Indebted Poor Countries (HIPC) Initiative, July 23, 1999 (IDA/SecM99-475, and EBS/99/138).
} 
provision of the full delivery of HIPC Initiative assistance, it is estimated that the NPV of debt-to-fiscal revenues (including new borrowing) will fall from 247 percent at end-2003 to 169 percent in 2004. Staff projections indicate that the ratio would fall steadily and remain below the HIPC threshold of 250 percent over the entire projection period, reaching 60 percent by the end of the projection period.

29. External debt service as a ratio to fiscal revenues after the full delivery of HIPC debt relief is expected to fall sharply after 2007 and would remain below 10 percent thereafter (Table 6). The debt service-to-fiscal revenues ratio in 2005 is estimated at 56.1 percent and would remain at elevated levels until end-2007, at which point debt relief and the high concessionality of new debt lower the ratio sharply. The normalization of relations with the international community requires a significant effort on the part of the authorities to mobilize resources for debt service over the 2006-07 period, but donor resources will also shoulder some of this burden. Moreover, from 2010 to the end of the projection period, the debt service burden will be at or below the average burden in other decision point HIPCs.

\section{E. Sensitivity Analysis}

30. Two alternative scenarios were carried out to test the sustainability of Congo's external debt after HIPC Initiative assistance (Table 8 and Figure 3). The significant worsening of the Congo's debt situation under both scenarios highlights the Congo's vulnerability to adverse shocks.

- One scenario considers the sensitivity of the projections to lower oil prices on exports and government revenues, assuming an unchanged level of external assistance and investment. Oil prices are assumed to fall by 25 percent throughout the forecast period relative to the baseline price assumptions; accompanying second-round effects on GDP growth are also included in this scenario. The ratio of the NPV of external debt-to-fiscal revenues rises significantly; over the period 2004-13 the ratio is on average higher by about 22 percentage points per year relative to the baseline scenario.

- The other scenario considers the impact of a two-percentage point lower non-oil GDP growth throughout the projection period. The impact of this shock, while not as pronounced over the medium term, increases over time as the share of the nonoil sector increases. The NPV of external debt-to-fiscal revenues over the period 2014-23 is higher by about 8 percentage points per year relative to the baseline scenario.

\section{The Decision And Floating Completion Points}

\section{A. PRSP Process}

31. The government prepared an interim PRSP, based on consultations with the population conducted in the second half of 2003. Despite limited data, the I-PRSP estimates 
that 50 percent of the population are poor, ${ }^{11}$ linking the high poverty incidence to the decline in per capita GDP in the 1990s and to the restricted access to basic social services. These, in turn, were caused initially by weak economic management and relative neglect of social development, and were subsequently aggravated by three episodes of civil strife in the 1990s. The participation process for a full PRSP will be broadened and deepened by including the input of civil society earlier in the design process.

32. The poverty reduction strategy proposed in the I-PRSP is based on 5 pillars:

(i) consolidation of peace and good governance; (ii) consolidation of macroeconomic stability and promotion of key economic sectors; (iii) improving access to basic social services and social protection; (iv) improving access to infrastructure; and (v) strengthening the fight against HIV/AIDS. Development of a full PRSP is planned for 2005, and would be ready in late 2006.

\section{B. Possible Decision Point Timing}

33. As noted in Section II.C, since 2002, Congo has made significant progress in strengthening the framework for peace and security, and restoring macroeconomic and financial stability. Assuming understandings are reached with the authorities on appropriate Completion Point triggers, continued satisfactory performance under the PRGF-supported program, and further progress is made toward debt reconciliation (including on outstanding questions related to SNPC's external financial obligations), the staffs recommend that the Decision Point document for Congo be considered by the Boards of their institutions by late 2005 on a stand-alone basis before the completion of the second PRGF review currently envisaged for February 2006. ${ }^{12}$

\section{Possible Triggers for the Decision and Floating Completion Points}

34. IDA and IMF staffs have reached preliminary understandings with the authorities on the nature of triggers for the completion point (Box 5). The first two and the last set of items in the box would be standard triggers, to be complemented by a satisfactory performance on specific and easily monitorable policy measures, aimed at strengthening the conditions for raising growth, and allowing Congo to make significant progress in achieving the MDGs. The policy measures would place special emphasis on pro-poor policy reforms and expenditure policy in education, health, basic infrastructure, social protection of vulnerable groups, the promotion of pro-poor growth, as well as improved transparency and

${ }^{11}$ This estimate is in contrast with the 70 percent estimate by the World Bank in 1996; the ongoing household survey is expected to provide a sound basis for examination of the poverty situation.

${ }^{12}$ At the time of the Board meeting in late 2005, staff will provide an update on macroeconomic performance (on the basis of the latest available information) and progress on structural reform implementation. 
accountability in financial management. The reforms will aim at fostering a policy climate conducive to private sector development, as well as at improving the efficiency in the allocation and use of scarce resources directly benefiting the poor. Should Congo remain on track with regard to implementation of its poverty reduction strategy and economic reforms supported by IDA and the IMF, the HIPC completion point could be reached in the second half of 2007 or the first half of 2008.

\section{Box 5. Possible Triggers for the Floating Completion Point}

1. PRSP implementation: preparation of full PRSP through a participatory process and its satisfactory implementation for at least one year, as evidenced by an Annual Progress Report that has been the subject of analysis in a Joint Staff Advisory Note.

2. Macroeconomic management: maintenance of macroeconomic stability as evidenced by satisfactory implementation of an ongoing IMF PRGF-supported program.

3. Public expenditure priorities: alignment of public spending priorities in accordance with the priorities identified in the I-PRSP, reflecting emphasis on pro-poor growth.

4. Public finance management: (i) preparation and execution of government budgets using a functional and economic budget classification system that also allows tracking of poverty-related spending; and (ii) reform of public procurement, including adoption and implementation of a new procurement code and key implementing decrees.

5. Natural resource management: measures to strengthen transparency and governance in the oil and forestry sectors (e.g., dissemination of information; reinforcement of SNPC's accounting system, internal control, and marketing; transparent revenue mobilization; forest management and forest law enforcement; and transparent adjudication of concessions in forestry).

6. Structural reforms: finalization of legal and regulatory framework to accompany public enterprise reform and privatization that would comprise, among others, measures to combat corruption and promote good governance.

7. Social development sectors: (i) measures to improve the quality of, and access to, health and education, especially at the primary level; (ii) increased awareness and prevention campaigns for HIV/AIDS and care for persons infected; and (iii) monitorable improvements in supplies of potable water, removal of waste waters, sanitation services, electricity in rural and urban communities, and road maintenance.

8. External debt management: (i) quarterly validation of external debt data and updating of debt service, including debt service projections; (ii) publication of the quarterly external debt data in an official statistical publication; and (iii) centralization of the government's oil related debt and financing information in the government's debt agency (CCA). 


\section{Monitoring the Use of HIPC Initiative Resources}

35. Securing the effective use of debt relief assistance for pro-poor growth and, more generally, the capacity to implement and monitor a shift in the composition of expenditure toward pro-poor growth objectives, is a key element of the HIPC Initiative. It will require continued efforts to strengthen the programming, management and control of expenditure, and to improve service delivery in key sectors. Within this framework, the technical assistance which will be provided in the area of public expenditure management by IDA and the IMF will be essential to restore an adequate budget management capacity.

36. The design of specific mechanisms for enhanced public expenditure management was addressed in the context of the first Public Expenditure Review (PER) conducted in 2004, a component of which will be dedicated to identifying the core priorities for spending on poverty reduction in line with the I-PRSP. These mechanisms should be targeted at identifying and classifying expenditures on specific poverty-related programs and projects in order to allocate and manage the use of HIPC Initiative assistance adequately. The PER final report is expected to be published in September 2005.

37. It remains important that poverty reduction programs supporting pro-poor growth be prepared according to standard budget procedures, with their eligibility for HIPC Initiative funding subject to the non-objection of the monitoring committee. These institutional arrangements will be designed to empower local communities to participate in defining development priorities and strategies, as well as in reviewing public expenditure programs and monitoring service delivery. Furthermore, the use of HIPC Initiative resources would be subject to independent technical and financial audits to ensure the effective use of these resources for poverty reduction, and all such audits would be made publicly available.

38. Finally, if the Decision Point is reached in late 2005, the poverty-related programs and projects to be financed with interim assistance would need to be included in the 2006 government budget. In view of the urgent need for reconstruction and rehabilitation, HIPC Initiative financing from debt relief is likely to focus on priority program areas summarized in Box 6. As stated above, these priorities would be refined, with the ongoing cooperation of IDA, the IMF, and other donors, in the context of the PER. 


\section{Box 6. Possible Expenditure Priorities}

\section{Governance}

- Improve citizen's access to information on public affairs, as a means to enhance transparency and accountability.

- $\quad$ Finance a results-based monitoring and evaluation system, as a management tool for efficient public resources utilization.

- Reform judicial system.

\section{Social Protection}

- Resettle and reintegrate ex-combatants.

- Reintegrate civil strife victims.

- Provide social safety nets linked to employment creation, especially for youth.

\section{Infrastructure/Urban}

- Rehabilitate roads, particularly rural access roads.

- Rehabilitate and expand coverage of water supply systems.

- Rehabilitate power grids.

\section{Health}

- Intervene to control the spread of HIV/AIDS.

- Promote immunization, good hygiene, the use of oral hydration salts, and good nutrition practices; the use of bed nets to prevent malaria, and condoms to prevent unwanted pregnancies and sexually transmitted diseases.

- Rehabilitate health infrastructure.

- Develop human resources.

- Strengthen the pharmaceutical sector.

\section{Education}

- Raise significantly the share of expenditures on education in total public expenditure.

- Hire additional teaching staff (for primary schools).

\section{Rural}

- Improve access to rural financial services.

- Improve rural roads.

- Improve policy formulation capacity in the Ministry of Agriculture. 


\section{ISSUES FOR DISCUSSION}

39. This paper presents a preliminary assessment of Congo's eligibility for assistance under the enhanced HIPC Initiative. Executive Directors' views and guidance are sought on the following issues:

- Eligibility: Do Directors agree that Congo is likely to meet the eligibility criteria under the fiscal window of the enhanced HIPC Initiative?

- Timing of the Decision Point: Do Executive Directors agree that Congo could reach its Decision Point by late 2005, that is, before the completion of the second review under the PRGF-supported program, provided that (i) the country remains on track with its macroeconomic program, supported by an arrangement under the PRGF, (ii) understandings are reached on appropriate Completion Point triggers, and (iii) further progress is made toward debt reconciliation (including on outstanding questions related to SNPC's financial obligations)?

- Floating Completion Point: What are Executive Directors' views on the possible triggers and key policy measures linked to the floating completion point?

- Commercial creditors: About a third of Congo's outstanding debt is owed to commercial creditors, a part of which is under litigation; this could complicate the enhanced HIPC Initiative process. Directors' views on the handling of this difficult issue would be appreciated. 
Figure 1. Republic of Congo: Net Present Value of Outstanding Debt at end-2003 by Creditor Group 1/

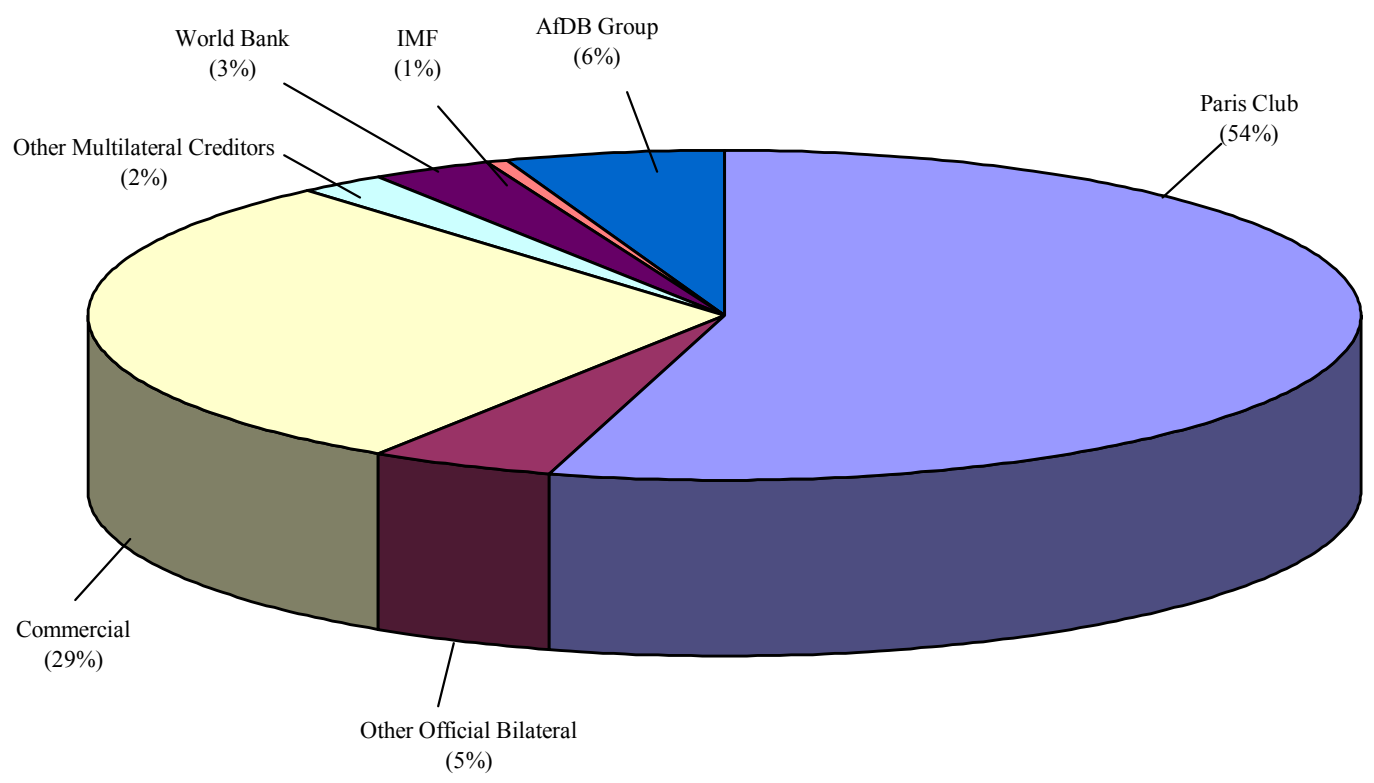

Sources: Congolese authorities; and staff estimates and projections.

1/ Assumes a hypothetical stock of debt operation on Naples terms at end-2003 on all Paris Club creditors and comparable treatment for other bilateral and commercial creditors. 
Figure 2. Republic of Congo: External Debt Sustainability Indicators, 2004-23 (In percent)



Debt service-to-revenue ratio

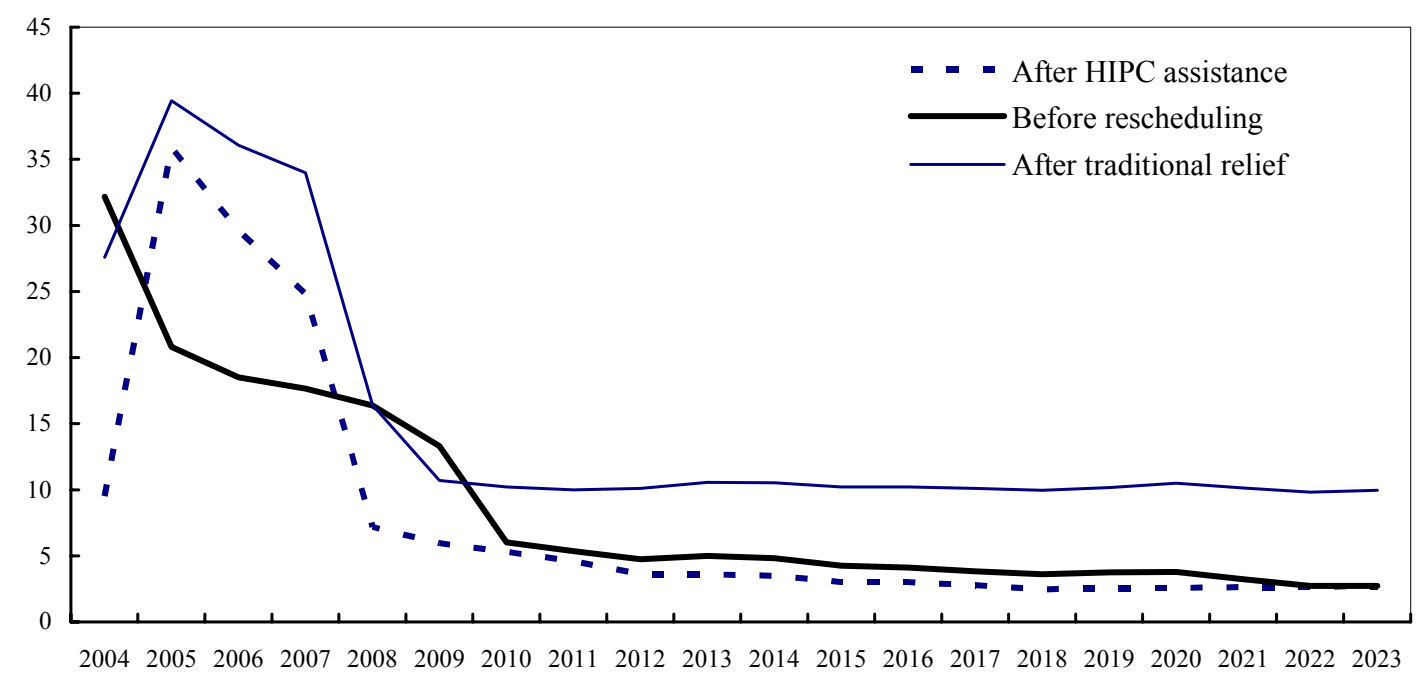

Sources: Congolese authorities; and staff estimates and projections. 
Figure 3. Republic of Congo: Sensitivity Analysis, 2004-23

(In percent)

NPV of debt-to-fiscal revenue ratio

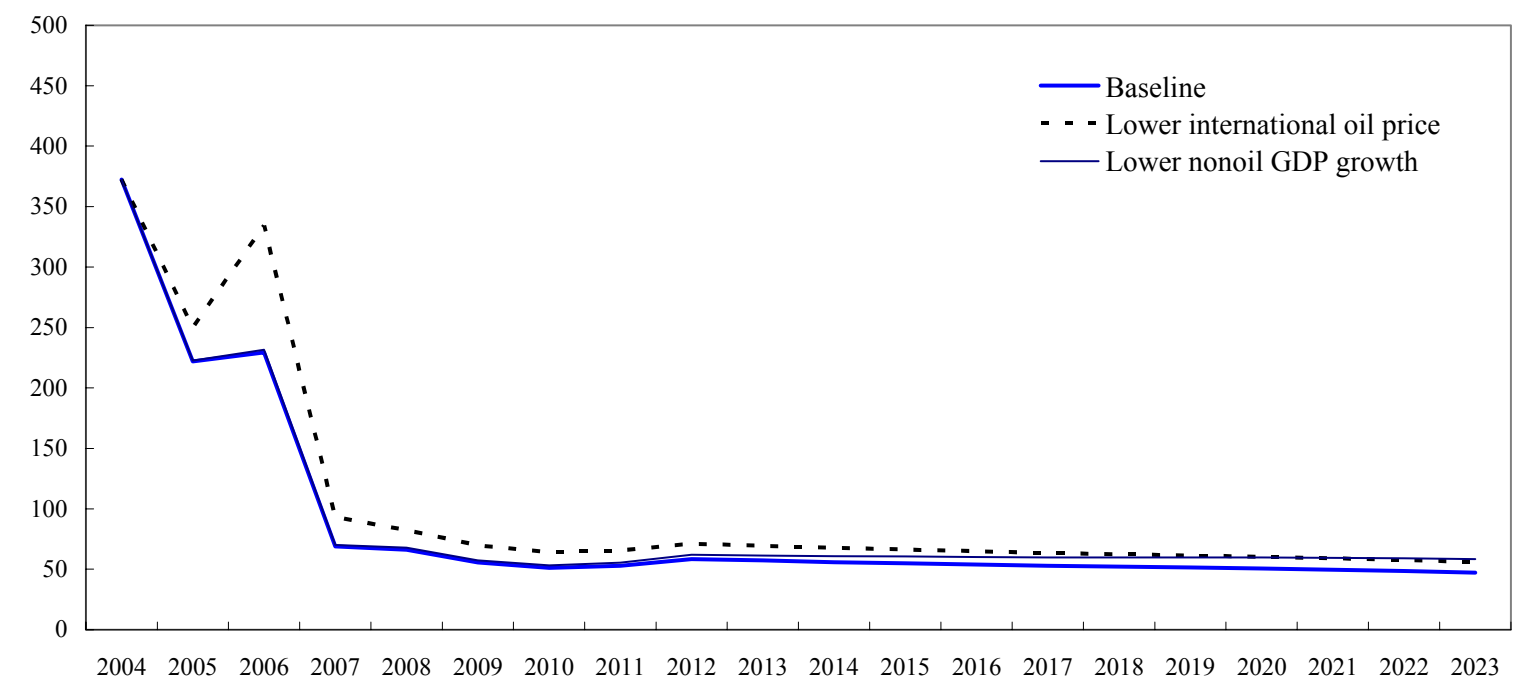

Debt service-to-fiscal revenue ratio

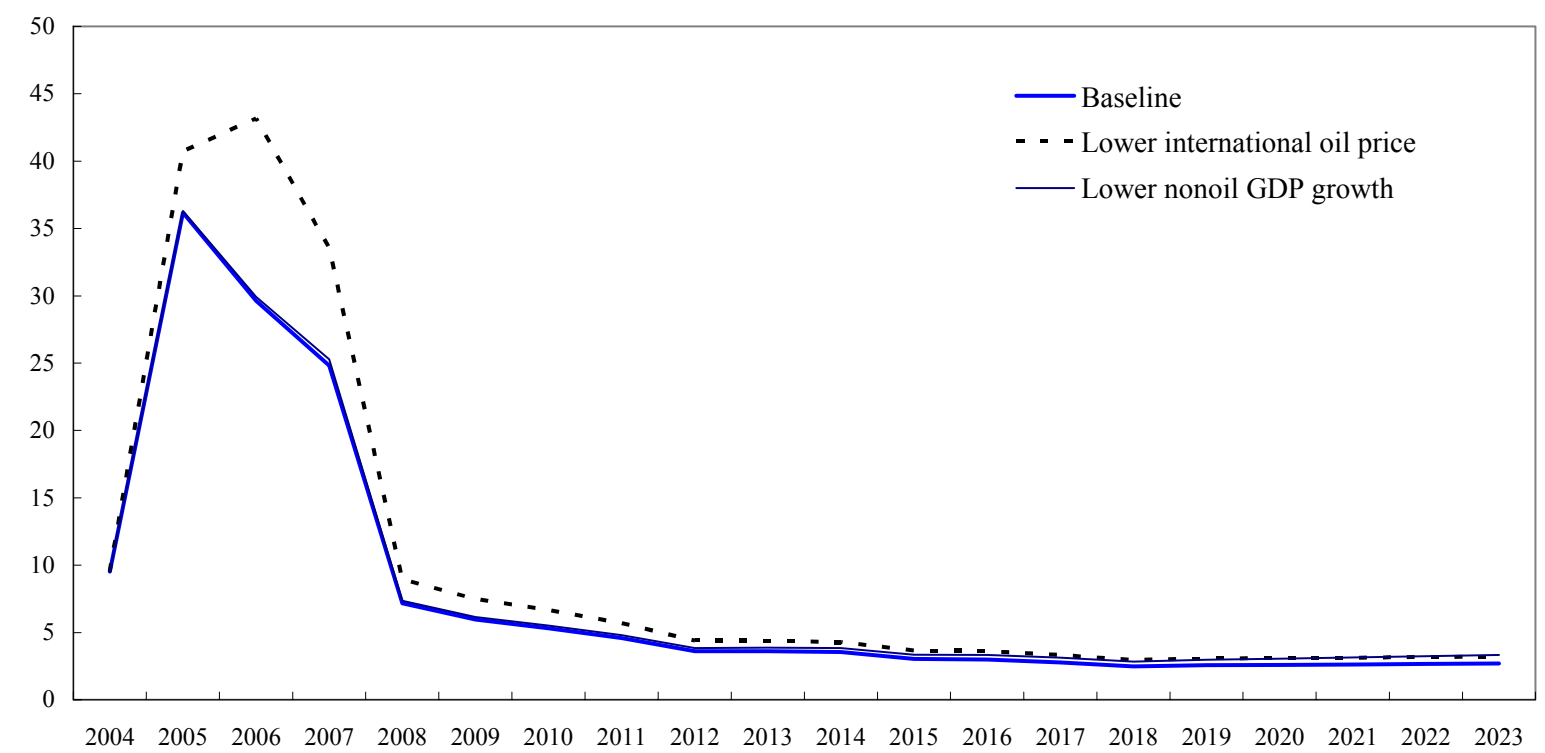

Sources: Congolese authorities; and staff estimates. 
Table 1. Republic of Congo: Selected Economic and Financial Indicators, 2001-07

\begin{tabular}{|c|c|c|c|c|c|c|c|}
\hline & 2001 & 2002 & 2003 & $\underline{2004}$ & 2005 & 2006 & 2007 \\
\hline & & & & Est & \multicolumn{2}{|c|}{ Projections } & \\
\hline & \multicolumn{7}{|c|}{ (Annual percentage change) } \\
\hline \multicolumn{8}{|l|}{ Production and prices } \\
\hline GDP at constant prices & 3.8 & 4.6 & 0.8 & 3.6 & 9.2 & 4.8 & 1.5 \\
\hline Oil & -7.5 & -1.5 & -7.2 & 0.5 & 16.7 & 3.3 & -6.3 \\
\hline Non-oil & 12.5 & 8.5 & 5.4 & 5.2 & 5.5 & 5.6 & 5.6 \\
\hline GDP at current prices & -10.7 & 2.8 & -1.6 & 10.8 & 17.0 & -0.2 & -2.8 \\
\hline GDP deflator & -13.9 & -1.7 & -2.4 & 6.9 & 7.2 & -4.8 & -4.2 \\
\hline Consumer prices (period average) & 0.8 & 3.1 & 1.5 & 3.6 & 2.0 & 2.0 & 2.0 \\
\hline \multicolumn{8}{|l|}{ External sector } \\
\hline Exports, f.o.b. (CFA francs) & -16.5 & 9.0 & -4.8 & 18.8 & 15.4 & -4.2 & -7.6 \\
\hline Imports, f.o.b. (CFA francs) & 17.8 & -1.5 & -4.4 & 21.1 & 7.4 & 3.9 & 0.7 \\
\hline Export volume & -14.0 & 3.5 & -5.5 & 8.6 & 14.9 & 3.1 & -3.9 \\
\hline Import volume & -10.1 & 34.7 & 2.9 & 16.7 & 11.6 & 5.4 & 1.5 \\
\hline Terms of trade (deterioration - ) & -10.7 & -0.3 & 2.9 & 12.5 & 4.7 & -4.2 & -4.0 \\
\hline Nominal effective exchange rate & 1.0 & 2.1 & 4.6 & 1.8 & $\ldots$ & $\ldots$ & $\ldots$ \\
\hline Real effective exchange rate & -0.4 & 3.5 & 2.2 & 1.1 & $\cdots$ & $\cdots$ & $\cdots$ \\
\hline \multicolumn{8}{|l|}{ Central government finances } \\
\hline Total revenue (including grants) & 3.7 & -8.9 & 6.6 & 21.6 & 37.2 & -11.2 & -12.4 \\
\hline of which: oil revenue & -7.6 & -7.7 & 6.1 & 25.8 & 49.7 & -17.6 & -20.5 \\
\hline non-oil revenue & 44.7 & -11.7 & 4.4 & 14.1 & 5.7 & 9.0 & 8.7 \\
\hline Total expenditure & 10.7 & 15.6 & -18.8 & 8.3 & -4.6 & 2.0 & 2.0 \\
\hline Current & 30.4 & 27.8 & -16.4 & 5.3 & -11.6 & 0.5 & 1.5 \\
\hline Capital & 28.8 & -10.7 & -26.0 & 18.5 & 17.1 & 5.5 & 3.3 \\
\hline & \multicolumn{7}{|c|}{ (In percent of beginning-of-period broad money) } \\
\hline \multicolumn{8}{|l|}{ Money and credit } \\
\hline Net domestic assets & 14.5 & 8.8 & 8.5 & -2.4 & -8.8 & -6.4 & -0.6 \\
\hline Domestic credit & 3.0 & -6.8 & 5.2 & 1.8 & -8.8 & -6.4 & -0.6 \\
\hline Central government & 21.0 & 9.0 & 0.4 & 0.3 & -10.8 & -8.3 & -2.6 \\
\hline Credit to the economy & -16.4 & -16.5 & 5.3 & 1.2 & 1.9 & 2.0 & 2.0 \\
\hline Broad money & -22.8 & 13.1 & -2.4 & 17.4 & 7.6 & 7.7 & 7.7 \\
\hline Velocity of broad money (non-oil) & 3.0 & 3.6 & 3.6 & 3.5 & 3.3 & 3.3 & 3.3 \\
\hline & \multicolumn{7}{|c|}{ (In percent of GDP) } \\
\hline \multicolumn{8}{|l|}{ Investment and saving } \\
\hline Gross national saving & 20.7 & 24.0 & 26.7 & 26.6 & 29.0 & 27.9 & 26.9 \\
\hline Gross investment & 26.4 & 23.4 & 25.7 & 24.2 & 24.1 & 24.9 & 25.0 \\
\hline Of which : public (domestically financed) & 9.8 & 7.6 & 5.4 & 5.3 & 5.7 & 5.9 & 6.1 \\
\hline \multicolumn{8}{|l|}{ Central government finances } \\
\hline Revenue and grants & 30.8 & 27.3 & 29.6 & 32.5 & 38.1 & 33.9 & 30.6 \\
\hline Total expenditure & 31.5 & 35.5 & 29.3 & 28.6 & 23.3 & 23.8 & 25.0 \\
\hline Overall fiscal balance (deficit -, commitment) 1 / & -0.7 & -8.1 & 0.4 & 3.9 & 14.8 & 10.1 & 5.5 \\
\hline Primary fiscal balance (deficit -) 2/ & 6.8 & 1.2 & 6.7 & 10.5 & 17.7 & 12.6 & 8.1 \\
\hline \multirow[t]{2}{*}{ Current account balance 3/ } & -5.6 & 0.6 & 1.0 & 2.3 & 4.9 & 3.0 & 2.0 \\
\hline & \multicolumn{7}{|c|}{ (In billions of CFA francs, unless otherwise indicated) } \\
\hline Gross official foreign reserves & 53.6 & 22.2 & 20.5 & 60.4 & 101.3 & 149.9 & 182.2 \\
\hline In months of imports, c.i.f.; in millions of U.S. dollars & 1.3 & 0.5 & 0.5 & 1.3 & 2.0 & 2.8 & 3.4 \\
\hline Nominal GDP & 2,048 & 2,105 & 2,072 & 2,294 & 2,685 & 2,679 & 2,604 \\
\hline World oil price (in U.S. dollars per barrel) 4/ & 24.3 & 24.9 & 28.8 & 38.2 & 45.2 & 39.8 & 37.0 \\
\hline Oil production (in millions of barrels) & 89.6 & 88.0 & 81.7 & 82.1 & 94.7 & 97.9 & 92.6 \\
\hline Potential windfall oil fiscal revenue 5/ & 0.0 & 0.0 & 0.0 & 0.0 & 82.8 & 121.8 & 106.5 \\
\hline
\end{tabular}

Sources: Congolese authorities; and Fund staff estimates and projections.

$1 /$ Including grants.

2/ Revenue (excluding grants) minus noninterest current expenditure minus domestically financed capital expenditure and net lending.

3/ Including public transfers.

4/ From 2005 onward, world oil price forecasts incorporate a prudence factor. As a result, WEO price forecasts are reduced by US\$4 per barrel.

5/ Additional revenue that would be generated by using WEO forecasts for world oil prices, that is, without applying the price rule. 
Table 2. Republic of Congo: Selected Indicators of Long-Term Macroeconomic Projections, 2005-23

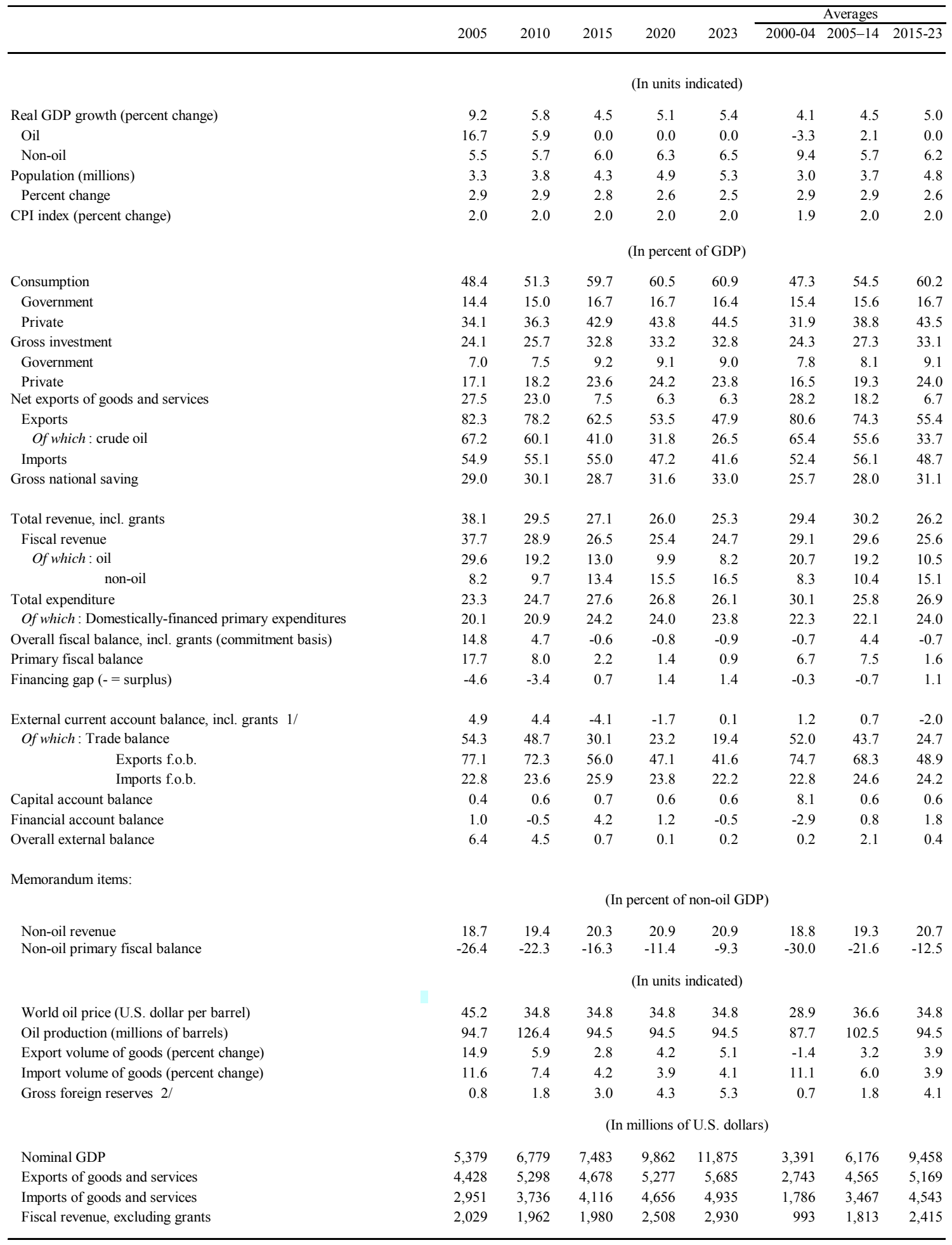

Sources: Congolese authorities; and staff estimates and projections.

1/ Before HIPC debt relief.

2/ In months of imports of goods and services. 
Table 3. Republic of Congo: Nominal Stock and Net Present Value of Debt at end-2003 by Creditor Group

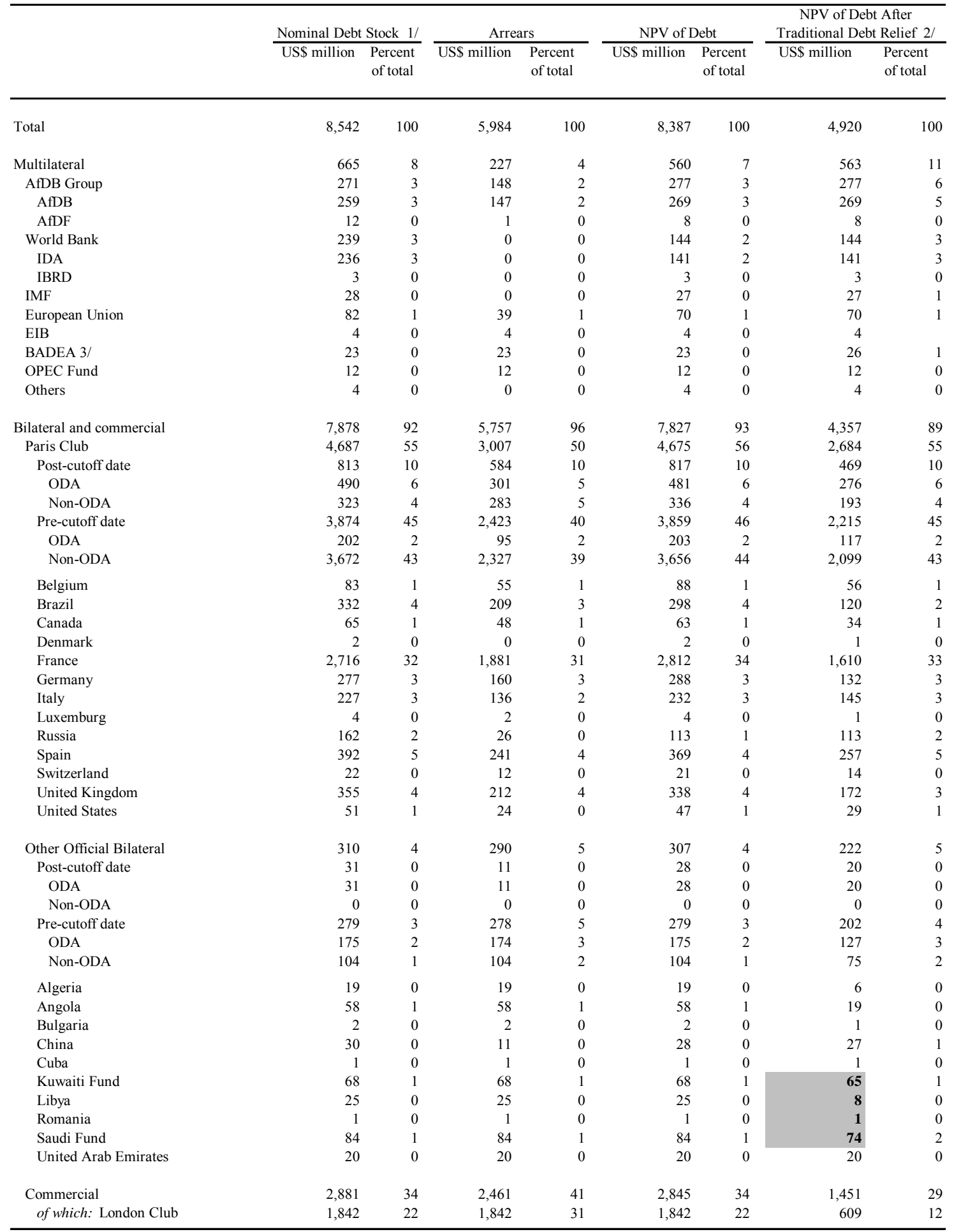

Sources: Congolese authorities; and Fund and Bank staff estimates.

$1 /$ Includes arrears.

2/ Includes a stock-of-debt operation on Naples terms at end 2003; and at least comparable action by other official bilateral and commercial creditors on eligible debt.

3/ Before the rescheduling of the arrears. 
Table 4. Republic of Congo: Net Present Value of External Debt, 2003-23 1/

(In millions of U.S. dollars, unless otherwise indicated)

\begin{tabular}{|c|c|c|c|c|c|c|c|c|c|c|c|}
\hline & & & & & & & & & & Aver & ages \\
\hline & 2003 & 2004 & 2005 & 2006 & 2007 & 2010 & 2015 & 2020 & 2023 & $2004-14$ & $2015-23$ \\
\hline I. Before traditional debt-relief & & & & & & & & & & & \\
\hline NPV of total debt & 8,385 & 8,067 & 7,781 & 7,567 & 7,391 & 7,059 & 7,063 & 7,109 & 7,186 & 7,310 & 7,109 \\
\hline NPV of outstanding debt & 8,385 & 8,046 & 7,732 & 7,486 & 7,271 & 6,814 & 6,633 & 6,457 & 6,375 & 7,104 & 6,501 \\
\hline Official bilateral and commercial & 7,827 & 7,525 & 7,225 & 7,000 & 6,813 & 6,395 & 6,287 & 6,146 & 6,089 & 6,670 & 6,184 \\
\hline Paris Club & 4,675 & 4,474 & 4,282 & 4,098 & 3,948 & 3,625 & 3,537 & 3,396 & 3,339 & 3,837 & 3,434 \\
\hline Other official bilateral & 307 & 304 & 302 & 299 & 296 & 291 & 290 & 290 & 290 & 294 & 290 \\
\hline Commercial & 2,845 & 2,746 & 2,642 & 2,603 & 2,569 & 2,479 & 2,461 & 2,461 & 2,461 & 2,539 & 2,461 \\
\hline Multilateral & 558 & 521 & 507 & 486 & 457 & 419 & 345 & 311 & 286 & 434 & 317 \\
\hline NPV of new borrowing & 0 & 21 & 49 & 81 & 120 & 246 & 430 & 652 & 810 & 205 & 608 \\
\hline II. After traditional debt-relief $2 /$ & & & & & & & & & & & \\
\hline NPV of total debt & 4,920 & 4,765 & 4,211 & 3,782 & 3,440 & 3,333 & 3,287 & 3,031 & 2,731 & 3,594 & 3,067 \\
\hline NPV of outstanding debt & 4,920 & 4,744 & 4,163 & 3,701 & 3,320 & 3,087 & 2,857 & 2,379 & 1,921 & 3,389 & 2,459 \\
\hline Official bilateral and commercial & 4,357 & 4,223 & 3,656 & 3,215 & 2,862 & 2,669 & 2,511 & 2,068 & 1,635 & 2,955 & 2,142 \\
\hline Paris Club & 2,684 & 2,651 & 2,346 & 2,081 & 1,867 & 1,771 & 1,690 & 1,420 & 1,186 & 1,934 & 1,471 \\
\hline Other official bilateral & 222 & 221 & 214 & 208 & 202 & 197 & 194 & 186 & 171 & 202 & 186 \\
\hline Commercial & 1,451 & 1,351 & 1,095 & 926 & 794 & 701 & 627 & 462 & 278 & 819 & 485 \\
\hline Multilateral & 563 & 521 & 507 & 486 & 457 & 419 & 345 & 311 & 286 & 434 & 317 \\
\hline NPV of new borrowing & 0 & 21 & 49 & 81 & 120 & 246 & 430 & 652 & 810 & 205 & 608 \\
\hline Memorandum items: & & & & & & & & & & & \\
\hline NPV of debt-to-exports ratio (percent) & & & & & & & & & & & \\
\hline Total debt & 197 & 160 & 116 & 92 & 81 & 69 & 72 & 59 & 49 & 87 & 61 \\
\hline Outstanding debt & 197 & 159 & 114 & 90 & 79 & 64 & 62 & 46 & 35 & 82 & 49 \\
\hline NPV of debt-to-revenue ratio (percent & & & & & & & & & & & \\
\hline Total debt & 473 & 341 & 208 & 211 & 220 & 170 & 166 & 121 & 93 & 206 & 130 \\
\hline Outstanding debt & 473 & 339 & 205 & 207 & 212 & 157 & 144 & 95 & 66 & 195 & 105 \\
\hline III. After enhanced HIPC assistance 4 & & & & & & & & & & & \\
\hline NPV of total debt & 8,242 & 5,211 & 4,504 & 4,103 & 1,076 & 1,004 & 1,088 & 1,269 & 1,382 & 2,009 & 1,230 \\
\hline NPV of total debt after full delivery $5 /$ & 2,572 & 2,376 & 1,785 & 1,366 & 1,076 & 1,004 & 1,088 & 1,269 & 1,382 & 1,255 & 1,230 \\
\hline Multilateral 6/ & 268 & 190 & 173 & 157 & 143 & 123 & 83 & 77 & 71 & 132 & 78 \\
\hline Bilateral and commercial & 2,303 & 2,165 & 1,563 & 1,128 & 813 & 636 & 575 & 540 & 500 & 918 & 545 \\
\hline NPV of outstanding debt & 8,242 & 5,190 & 4,455 & 4,022 & 956 & 759 & 658 & 617 & 572 & 1,803 & 622 \\
\hline Official bilateral and commercial & 7,827 & 4,858 & 4,147 & 3,735 & 813 & 636 & 575 & 540 & 500 & 1,635 & 545 \\
\hline Paris Club & 4,675 & 3,194 & 2,819 & 2,585 & 572 & 490 & 449 & 418 & 384 & 1,143 & 422 \\
\hline Other official bilateral & 307 & 222 & 214 & 207 & 88 & 83 & 83 & 83 & 84 & 120 & 83 \\
\hline Commercial & 2,845 & 1,442 & 1,113 & 944 & 152 & 62 & 43 & 39 & 33 & 372 & 39 \\
\hline Multilateral & 415 & 331 & 308 & 287 & 143 & 123 & 83 & 77 & 71 & 169 & 78 \\
\hline NPV of new borrowing & 0 & 21 & 49 & 81 & 120 & 246 & 430 & 652 & 810 & 205 & 608 \\
\hline Memorandum items: & & & & & & & & & & & \\
\hline NPV of debt-to-exports ratio (percent) & & & & & & & & & & & \\
\hline Total debt & 330 & 175 & 124 & 99 & 25 & 21 & 24 & 25 & 25 & 53 & 24 \\
\hline Total debt, assuming full delivery & 103 & 80 & 49 & 33 & 25 & 21 & 24 & 25 & 25 & 31 & 24 \\
\hline Outstanding debt & 330 & 174 & 122 & 98 & 23 & 16 & 14 & 12 & 10 & 48 & 12 \\
\hline NPV of debt-to-revenue ratio (percent & & & & & & & & & & & \\
\hline Total debt & 792 & 373 & 222 & 229 & 69 & 51 & 55 & 51 & 47 & 117 & 51 \\
\hline Total debt, assuming full delivery & 247 & 170 & 88 & 76 & 69 & 51 & 55 & 51 & 47 & 73 & 51 \\
\hline Outstanding debt & 792 & 371 & 220 & 225 & 61 & 39 & 33 & 25 & 20 & 106 & 26 \\
\hline
\end{tabular}

Sources: Congolese authorities and staff estimates and projections.

1/ All debt refers to public and publicly guaranteed debt.

2/ Shows the external debt situation after the full use of traditional debt-relief mechanisms, and assuming at least comparable treatment from official bilateral creditors.

3/ In terms of simple historical three-year average of exports of goods and services.

4/ Assumes interim relief under the enhanced Initiative from December 2005 to December 2007 and full delivery of assistance in December 2007.

5/ NPV of debt shows the results of the (hypothetical) full delivery of the enhanced HIPC assistance at end 2003.

6/ The NPV of multilteral debt is net of $\$ 38$ million of arrears cancelled by the EU. In 2004, the EU agreed to cancel

outstanding arrears, using grants already committed for future disbursements. Given the additional nature of HIPC relief and

future assistance, the amount cancelled has not been counted toward the delivery of the EU share of HIPC relief. 
Table 5. Republic of Congo: HIPC Initiative

Assistance Under a Proportional Burden-Sharing Approach 1/ 2/

(In millions of U.S. dollars, unless otherwise indicated)

\begin{tabular}{|c|c|c|c|c|}
\hline $\begin{array}{l}\text { NPV of debt- } \\
\text { to-revenue-target } \\
\text { (in percent) }\end{array}$ & $\begin{array}{r}\text { Total } \\
\text { (In NPV terms } \\
\text { at end 2003) }\end{array}$ & Bilateral 3/ & Multilateral & $\begin{array}{r}\text { Common Reduction } \\
\text { factor } 4 / \\
\text { (Percent) }\end{array}$ \\
\hline 250 & 2,319 & 2,054 & 265 & 47.1 \\
\hline NPV of debt $5 /$ & 4,920 & 4,357 & 563 & \\
\hline Paris Club creditors & 2,684 & & & \\
\hline Of which: Pre-cutoff date non-ODA debt & 2,099 & & & \\
\hline Non-Paris Club creditors & 1,673 & & & \\
\hline Of which: Pre-cutoff date non-ODA debt & 104 & & & \\
\hline commercial creditors & 1,451 & & & \\
\hline Central government revenues $6 /$ & 1,040 & & & \\
\hline NPV of debt-to-revenue ratio (percent) & 473 & & & \\
\hline
\end{tabular}

Sources: Congolese authorities and staff estimates and projections.

1/ The proportional burden sharing approach is described in "HIPC Initiative--Estimated Costs and burden sharing Approaches" (EBS/97/127, 7/7/97 and IDA/SEC M 97-306, 7/7/97).

$2 /$ Includes a hypothetical stock-of-debt operation on Naples terms (December 2003) and comparable treatment by other official bilateral creditors.

3/ Includes official bilateral creditors and commercial debt.

4/ Each creditor's NPV reduction in percent of its exposure at the decision point.

5/ Based on end-2003 data after full application of traditional debt relief mechanisms.

6/ Excludes grants. 
Table 6. Republic of Congo: External Debt Service, 2004-23 1/

(In millions of U.S. dollars, unless otherwise indicated)

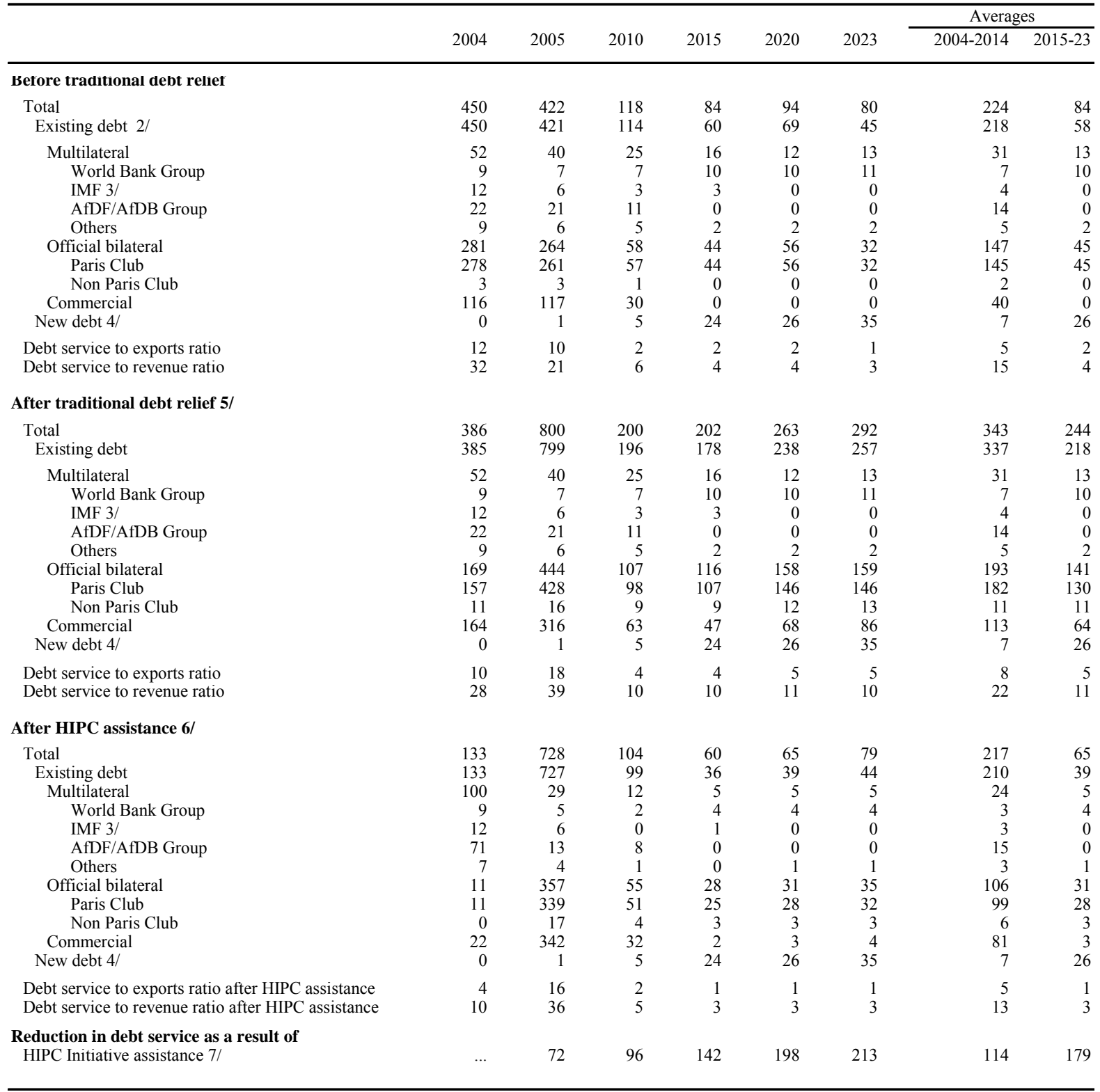

Sources: Congolese authorities and staff estimates and projections.

1/ All debt indicators refer to public and publicly guaranteed (PPG) debt and are defined after rescheduling, unless otherwise indicated.

2/ Includes only scheduled debt service on current maturities and does not include projected penalty interest on arrears.

3/ From 2005, IMF debt service includes repayments of the first tranche of the PRGF disbursed in December 2004 and repayments of the second tranche of the PRGF assumed to be disbursed in August 2005.

4/ Reflects the borrowing needed to close the gap.

5/ Assumes a hypothetical stock of debt operation on Naples terms and comparable treatment from other bilateral creditors; excludes multilateral arrears clearance.

6/ Assumes full delivery of HIPC assistance through a Cologne flow treatment between December 2005 and December 2007, and a Cologne stock of debt treatment at completion point from Paris Club and commercial creditors. Multilateral creditors are also assumed to provide their share of HIPC debt relief as of the completion point, except for the IMF, the World Bank and the AfDB, for which the delivery would start as of the decision point (June 2005).

7/ The reduction is measured as the difference between the projected debt service after full use of traditional debt relief mechanisms and the debt sevice after full HIPC relief. 
Table 7. Republic of Congo: External Debt Indicators, 2003-23 1/

(In percent, unless otherwise indicated)

\begin{tabular}{|c|c|c|c|c|c|c|c|}
\hline & 2003 & 2004 & 2005 & 2010 & 2015 & 2020 & 2023 \\
\hline \multicolumn{8}{|l|}{ After traditional debt relief mechanisms $2 /$} \\
\hline NPV of debt-to-GDP ratio & 138 & 110 & 78 & 49 & 44 & 31 & 23 \\
\hline NPV of debt-to-exports ratio $3 /$ & 197 & 160 & 116 & 69 & 72 & 59 & 49 \\
\hline NPV of debt-to-revenue ratio 4/ & 473 & 341 & 208 & 170 & 166 & 121 & 93 \\
\hline Debt service-to-exports ratio & $\ldots$ & 10 & 18 & 4 & 4 & 5 & 5 \\
\hline Debt service-to-revenue ratio $4 /$ & $\ldots$ & 28 & 39 & 10 & 10 & 11 & 10 \\
\hline \multicolumn{8}{|l|}{ After conditional delivery of enhanced HIPC assistance } \\
\hline NPV of debt-to-GDP ratio & 231 & 120 & 84 & 15 & 15 & 13 & 12 \\
\hline NPV of debt-to-exports ratio $3 /$ & 330 & 175 & 124 & 21 & 24 & 25 & 25 \\
\hline NPV of debt-to-exports ratio (existing debt only) & 330 & 174 & 122 & 16 & 14 & 12 & 10 \\
\hline NPV of debt-to-revenue ratio 4 / & 792 & 373 & 222 & 51 & 55 & 51 & 47 \\
\hline Debt service-to-exports ratio & $\ldots$ & 4 & 16 & 2 & 1 & 1 & 1 \\
\hline Debt service-to-revenue ratio $4 /$ & $\ldots$ & 10 & 36 & 5 & 3 & 3 & 3 \\
\hline \multicolumn{8}{|c|}{ After unconditional delivery of enhanced HIPC assistance 5/ } \\
\hline NPV of debt-to-GDP ratio & 72 & 55 & 33 & 15 & 15 & 13 & 12 \\
\hline NPV of debt-to-exports ratio 3/ & 103 & 80 & 49 & 21 & 24 & 25 & 25 \\
\hline NPV of debt-to-revenue ratio 4/ & 247 & 170 & 88 & 51 & 55 & 51 & 47 \\
\hline \multicolumn{8}{|l|}{ Memorandum items (in millions of U.S. dollars): } \\
\hline Debt service after enhanced HIPC assistance 6/ & $\ldots$ & 133 & 728 & 104 & 60 & 65 & 79 \\
\hline GDP & 3571 & 4349 & 5379 & 6779 & 7483 & 9862 & 11875 \\
\hline Exports of goods and services & 2831 & 3674 & 4428 & 5298 & 4678 & 5277 & 5685 \\
\hline Exports of goods and services (three-year avg.) 3/ & 2499 & 2979 & 3644 & 4830 & 4586 & 5160 & 5544 \\
\hline Government revenue 4/ & 1040 & 1399 & 2029 & 1962 & 1980 & 2508 & 2930 \\
\hline
\end{tabular}

Sources: Congolese authorities; and staff estimates and projections.

1/ All debt indicators refer to public and publicly guaranteed (PPG) debt and are defined after rescheduling, unless otherwise indicated.

2/ Reflect a hypothetical stock-of-debt operation on Naples terms at end-2003 for Paris Club creditors as calculated in the HIPC decision point document.

3/ Based on a three-year average of exports on the previous year (e.g., export average over 2001-03 for NPV of debt-to-exports ratio in 2003).

4/ Revenue is defined as central government revenue, excluding grants.

5/ NPV of debt shows the results of the (hypothetical) full delivery of the enhanced HIPC assistance at end 2003.

6/ Assuming full delivery of HIPC assistance at end-December 2007. 
Table 8. Republic of Congo: External Debt Indicators and Sensitivity Analysis, 2004-23 1/

\begin{tabular}{|c|c|c|c|c|c|c|c|c|}
\hline & \multirow{2}{*}{$\frac{2004}{\text { Est. }}$} & \multirow[t]{2}{*}{2005} & \multirow[t]{2}{*}{2010} & \multirow[t]{2}{*}{2015} & \multirow[t]{2}{*}{2020} & \multirow[t]{2}{*}{2023} & \multicolumn{2}{|c|}{ Averages } \\
\hline & & & & & & & $2004-14$ & $2015-23$ \\
\hline & \multicolumn{8}{|c|}{ (In percent; unless otherwise indicated) } \\
\hline \multicolumn{9}{|l|}{ Baseline scenario } \\
\hline NPV of debt-to-GDP ratio & 120 & 84 & 15 & 15 & 13 & 12 & 37 & 13 \\
\hline NPV of debt-to-exports ratio $2 /$ & 142 & 102 & 19 & 23 & 24 & 24 & 47 & 24 \\
\hline NPV of debt-to-revenue ratio 3/ & 373 & 222 & 51 & 55 & 51 & 47 & 117 & 51 \\
\hline Debt service to export ratio & 4 & 16 & 2 & 1 & 1 & 1 & 5 & 1 \\
\hline Debt service to revenue ratio & 10 & 36 & 5 & 3 & 3 & 3 & 12 & 3 \\
\hline \multicolumn{9}{|l|}{ Sensitivity analysis } \\
\hline \multicolumn{9}{|l|}{ Lower oil price scenario 4/ } \\
\hline NPV of debt-to-exports ratio $2 /$ & 142 & 117 & 25 & 29 & 29 & 29 & 56 & 29 \\
\hline NPV of debt-to-revenue ratio $3 /$ & 373 & 250 & 64 & 66 & 60 & 56 & 140 & 61 \\
\hline Debt service to export ratio & 4 & 19 & 3 & 2 & 1 & 2 & 6 & 2 \\
\hline Debt service-to-revenue ratio 3/ & 10 & 40 & 7 & 4 & 3 & 3 & 15 & 3 \\
\hline \multicolumn{9}{|l|}{ Non oil GDP shock 5/ } \\
\hline NPV of debt-to-exports ratio $2 /$ & 142 & 102 & 20 & 26 & 28 & 28 & 48 & 27 \\
\hline NPV of debt-to-revenue ratio $3 /$ & 373 & 223 & 53 & 60 & 60 & 58 & 120 & 60 \\
\hline Debt service to export ratio & 4 & 17 & 2 & 1 & 1 & 2 & 5 & 1 \\
\hline Debt service-to-revenue ratio 3/ & 10 & 36 & 6 & 3 & 3 & 3 & 12 & 3 \\
\hline
\end{tabular}

Sources: Congolese authorities; and staff estimates and projections.

1/ All debt indicators refer to public and publicly guaranteed (PPG) debt and are defined after HIPC assistance assumed delivered unconditionally at end-2003.

2/ Based on a three-year average of exports on the previous year (e.g., export average over 2001-04 for

NPV of debt-to-exports ratio in 2004).

$3 /$ Revenue is defined as central government revenue, excluding grants.

4/ Assumes that international oil price would drop by 25 percent.

5/ Assumes a drop of 2 percentage point of real non-oil GDP growth. 


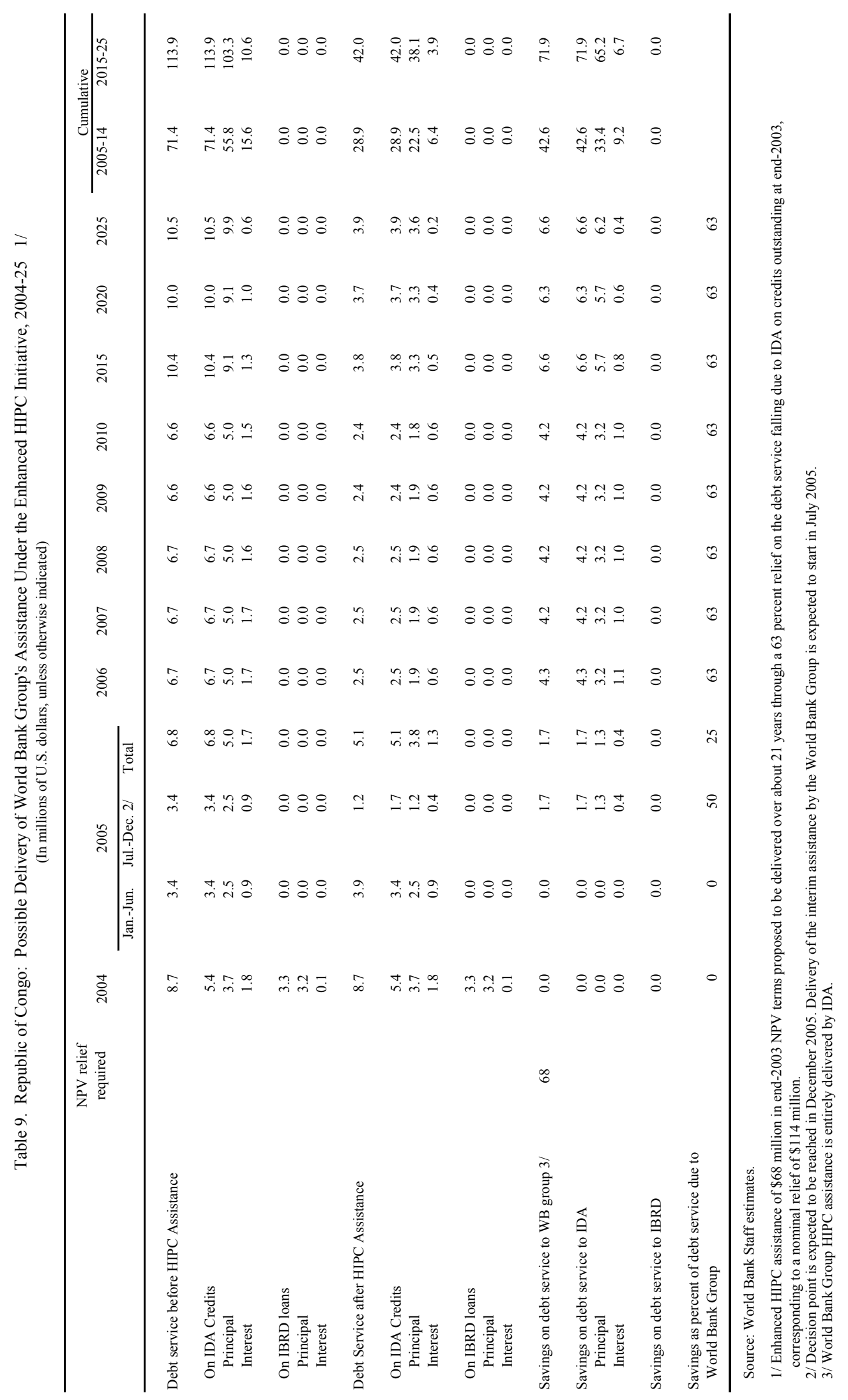




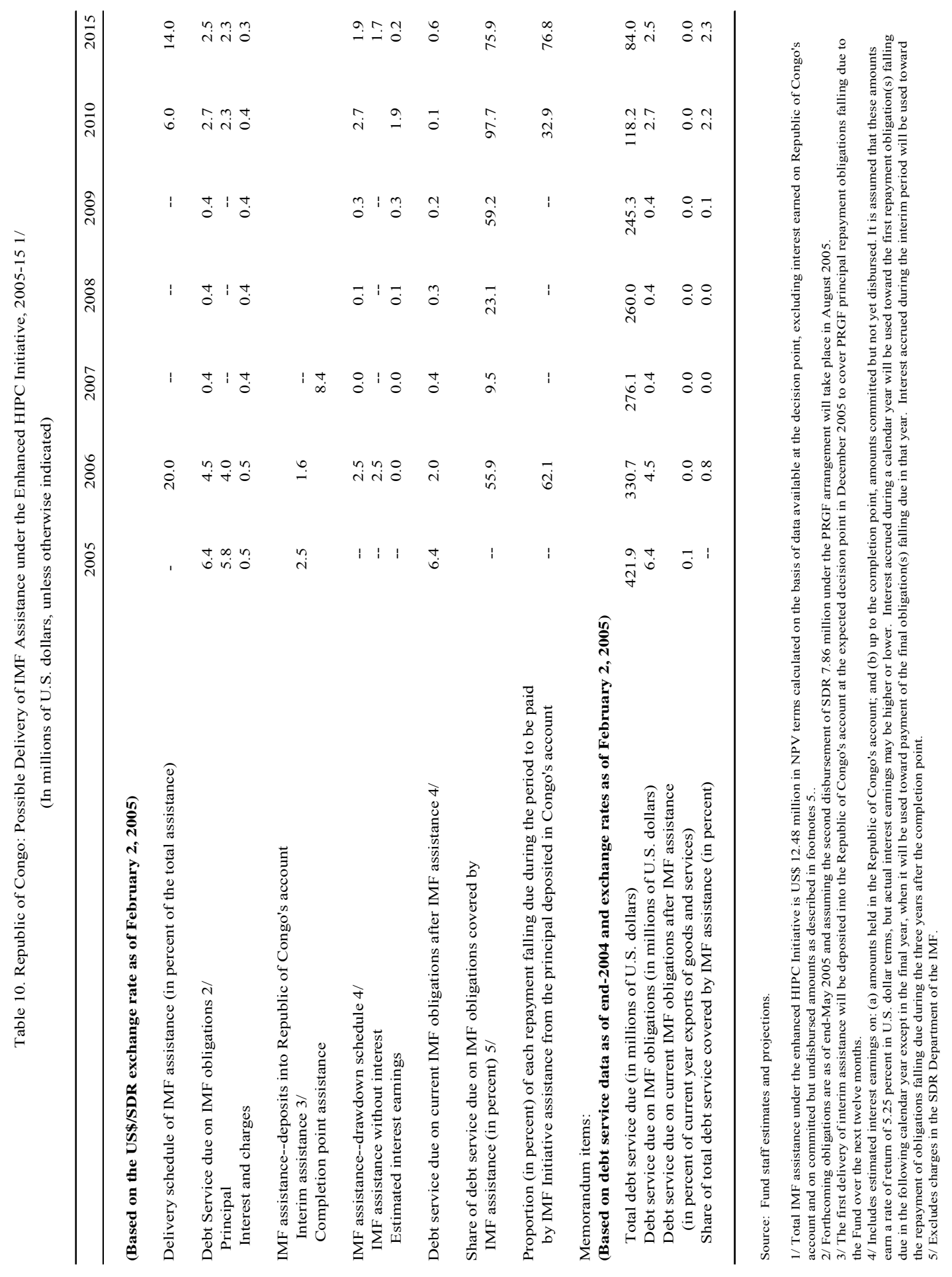




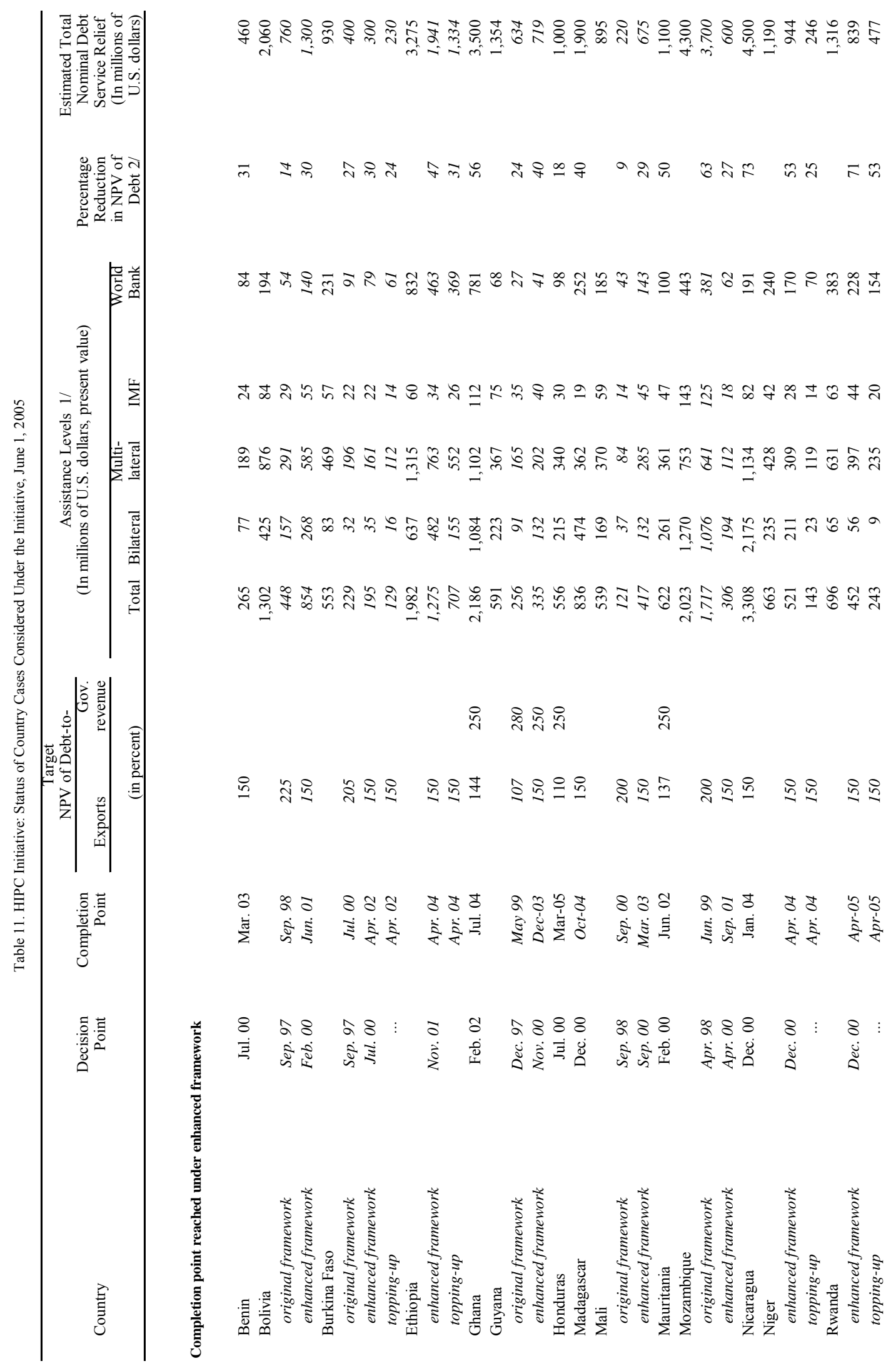




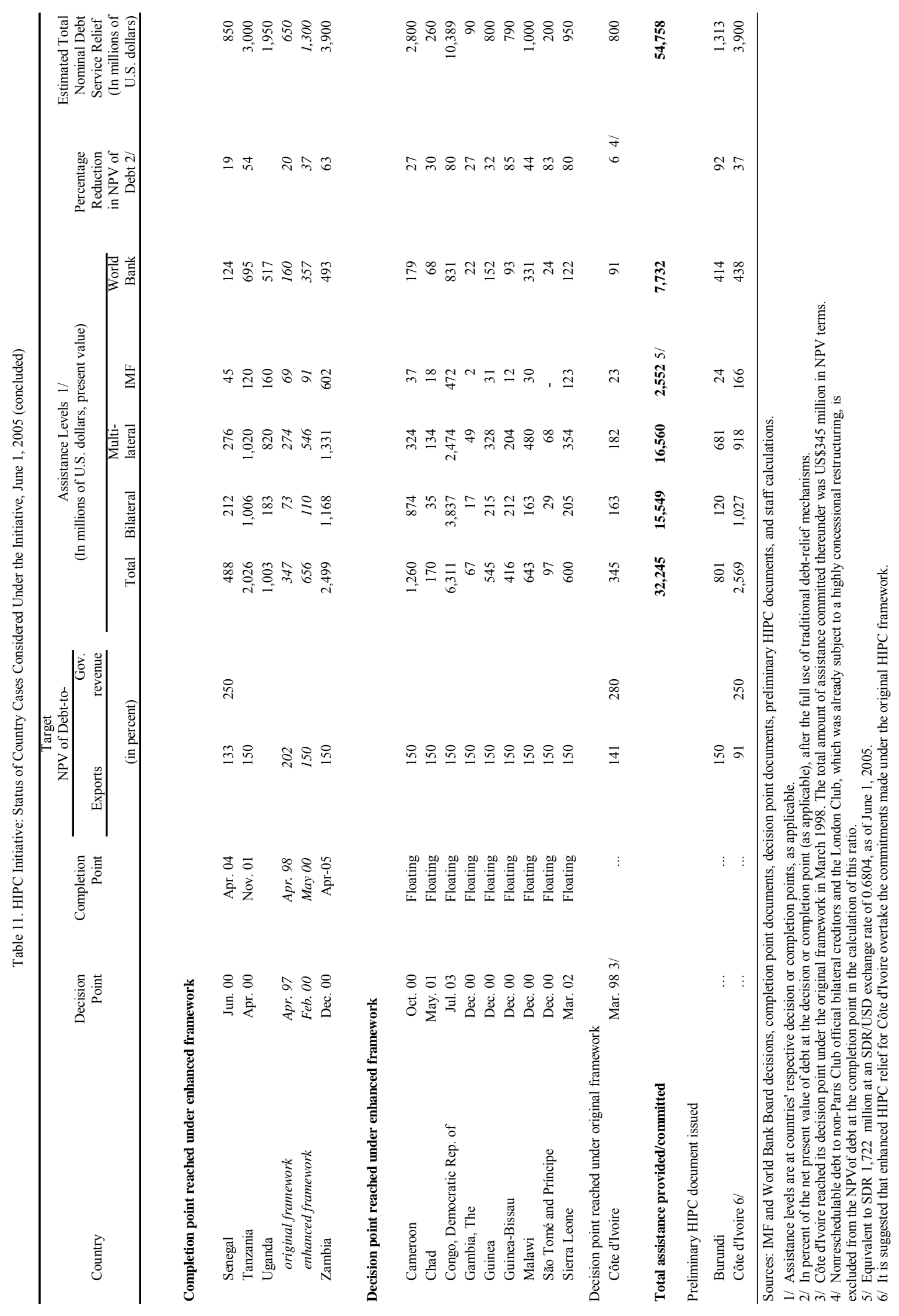




\section{National Oil Company Financial Obligations}

\section{INTRODUCTION}

1. Public enterprise external debt has been included in the debt sustainability analysis (DSA) with the exception of debt held by the national oil company, Societé Nationale des Petroles du Congo (SNPC). ${ }^{1}$ A number of issues relating to the inclusion of this debt in the DSA need to be resolved.

2. Among Congolese public enterprises, the SNPC stands out. It is by far the largest enterprise and has a special corporate governance structure that permits it to operate independently on a commercial basis. The SNPC has also been entrusted with important fiscal agency functions in the oil sector, notably the management of the state's oil assets and the marketing of the state's in-kind oil revenue deriving from the production sharing agreements (PSAs).

3. The SNPC's assets - estimated at end-2003 at US\$1.2 billion-largely consist of its equity participations in oil exploration and exploitation joint ventures with private oil companies, with shares ranging from 15 to 50 percent. The company's capital is relatively small, however, as these assets are offset by large liabilities, mostly balances in overdraft accounts with joint venture partners, as well as substantial financial and other debts. The SNPC has relatively easy access to external financing, thanks to its steady oil income from equity participations plus its role as marketer of the government's fiscal oil.

4. The authorities have provided extensive relevant information to the Fund and World Bank staffs, and are committed to resolving outstanding questions.

\section{OVERDRAFT DEBT}

5. The SNPC's overdraft debt — totaling some US\$954 million at end-2003 - is the result of the fact that the SNPC (and its predecessor HydroCongo) did not pay cash for its share in the various joint ventures in which it participates, but instead borrowed the funds for covering exploration and initial exploitation costs from its joint-venture partners. Because those costs are incurred over a number of years, the partners lend to the SNPC in installments by debiting "advance accounts." The joint venture contracts stipulate that the advance accounts will be reimbursed from the SNPC's equity oil income once oil production starts. However, until there is sufficient production, exploitation and interest costs continue to be debited to the advance accounts. The objective of this so called "carried interest"

\footnotetext{
${ }^{1}$ Besides central government external debt, the enhanced HIPC Initiative covers majoritygovernment-owned public enterprise external debt, whether or not it is government guaranteed.
} 
construction, which is common in the oil industry, is to permit governments in developing countries to participate in oil joint ventures despite the liquidity constraints they typically face. Since the reimbursement is only from oil income, the financial obligation is contingent: if no oil is found, the government has no liability. The total reimbursement in any period is limited to a portion of the oil income, intended to ensure to the SNPC a minimum cash flow, but also slowing the re-imbursement rate in the process.

6. At its creation in 1998, the SNPC took over eight such overdraft accounts - together with all other assets and liabilities - from the state-oil company it replaced, Hydro-Congo. These overdraft accounts are governed by four joint-venture agreements, signed in the early 1970s and late 1980s. At end-2003, the balances in those accounts totaled US\$954 million. Three issues remain to be resolved with respect to the eligibility of any of these advance accounts before their inclusion in the DSA:

- First, there is a question as to whether or not any balance in these accounts can be considered debt, given that reimbursement is from oil income and therefore contingent on the existence of oil income.

- Second, if these advances are debt, it depends on the legal status of the creditor (i.e., country of legal residency) whether they are external or domestic debt.

- Third, if it is determined that part of these balances is external debt, the stock at end 2004 needs to be determined and reconciled with the creditors, and a debt service profile needs to be established.

7. Based on the available information, the Fund and the Bank staff have come to the following preliminary views:

- First, it is not clear whether these overdraft balances are debt. Staff continues to examine this issue with a view to having a definitive answer at the time of the Decision Point under the enhanced HIPC Initiative document. On the one hand, these obligations do not appear to be debt. Due to the contingent nature of the advance accounts, any payment is fully linked to the existence of oil revenues and no direct transfer from the government or state-owned enterprise takes place in the absence of oil revenues. These liabilities represent amounts due by the SNPC to private partners for the equity share paid by the latter on its behalf in the context of joint commercial ventures, with understandings that part of SNPC equity income will be used to reimburse the partners. On the other hand, the "carried interest" debt appears to be 
similar to "production payments" which are treated by the U.S. Internal Revenue Service as a mortgage loan on property, i.e., the joint venture participation. ${ }^{2}$

- Second, of the eight creditors at end-2003, two appear to be Congolese resident companies; if confirmed, this would reduce the financial obligations that could be possibly be considered as external debt from US\$954 million to US\$489 million.

- Third, staff has estimated the total balances in the advance accounts, US\$954 million, from statements provided by the joint venture partners. However, it is important to take into consideration the concerns expressed by the external auditors of the SNPC in their report on 2003 regarding the lack of reconciliation between the SNPC and its joint venture partners of the balances in the overdraft accounts.

\section{OTHER DEBT AND GUARANTEES}

8. At end-2003, the external audit report lists US\$615 million in "loans and various financial debts" (US\$235 million) and "other debts" linked to transactions for the government (US\$357 million). About US\$380 million of this total "other" debt consists of oil-collateralized loans that are already captured in the DSA. The remaining amount consists of domestic debt to suppliers of the national oil refinery (US\$20 million), SNPC debt to the government for government oil sold but not yet cashed (US\$87 million), and a remaining liability (US\$67 million) that consists of amounts that still need to be regularized.

9. The authorities, when requested, confirmed the absence of guarantees between the SNPC and external parties.

2 See "Production Payments in International Oil and Gas Operations: Using a U.S. Financial Tool Overseas." by John Bradford and Morgan Holtman, International Tax Review, September 2004. 


\section{Debt MANAgEMENT CAPACiTy}

1. The debt management agency is able to produce electronic reports on public and publicly guaranteed external debt, but its computer system needs improvement. ${ }^{1}$ The CCA's computers are not linked, and only one computer has the debt software necessary to produce the debt statistics. Data are entered manually into another computer that contains Excel templates with summary information on individual loans. Differences in accounting methods and irregular updates of interest and exchange rates can lead to errors in the estimates of outstanding stock of debt.

2. The CCA's debt statistics are not comprehensive. Detailed information on debt contracted by SNPC, or other state-owned enterprises, is not included in the system, but kept in paper format, while the source documentation is retained by the SNPC. Moreover, the CCA lacks the capacity to track commercial debt under litigation, nor does it maintain an updated list of funds that have bought Congo's external debt on the secondary market.

3. A modern debt reporting system is being installed. ${ }^{2}$ When the system is fully operational and covers all relevant debt with the necessary detail, the CCA will be able to produce basic debt statistics for publication, domestically and externally, for instance in the Global Development Finance report. According to a survey carried out by the World Bank, CCA staff has a need for training in three main areas: (1) legal aspects of debt negotiation procedures and of the contracting of new debt, (2) macroeconomic analysis related to debt sustainability, and (3) computer software utilization. A sufficiently large number of staff should be trained in order to ensure continuity of operations.

4. Looking ahead, Congo needs to further strengthen its debt management and reporting capacity, centralize all debt information at the CCA, continue improving relations with all creditors, and start regular data dissemination to the public.

\footnotetext{
${ }^{1}$ The Caisse Congolaise d'Amortissement (CCA) at the Ministry of Finance is the sole agency responsible for the collection of debt statistics and debt management.

2 It is the UNCTAD's debt management system (or DMFAS, version 5.3).
} 